Our Nature (2010) 8: 270-312

\title{
Potential Impacts of Agriculture on Nepal Birds
}

\author{
C. Inskipp ${ }^{1}$ and H.S. Baral ${ }^{2}$ \\ ${ }^{1}$ Herneside, March Road, Welney, Wisbech, Cambridgeshire PE14 9SB, UK. \\ E-mail: inskipp@btinternet.com \\ ${ }^{2}$ PO Box 10918, Himalayan Nature, Lazimpat, Kathmandu, Nepal \\ E-mail: hem.baral@gmail.com
}

Received: 21.09.2010, Accepted: 11.11.2010

\begin{abstract}
This paper is a review of the potential impacts of agriculture on Nepal birds. It includes an overview of agriculture in Nepal and the changes that have taken place between the early 1950s and 2007. Agricultural development has been sluggish, and has failed to keep pace with population growth. In recent years the yields of major food crops in Nepal have been lower than other South Asian countries and Nepal is now dependent on food imports. Land holding size per family and field sizes have both decreased markedly during the period. If hill regions are considered independently, all cereal crops yields have stagnated in the last 30 years and gains in production that have been made, have been due to increases in area of cultivation, at the expense of natural habitats: forests, wetlands and grasslands. Crop productivity in the hills has declined due to land degradation. Of the $28 \%$ of Nepal land that is degraded, $10 \%$ is poorly managed sloping agriculture terraces. As yields and production of cereal crops have fallen, many farmers have shifted to growing cash crops, to meet the demands of the increasing urban population and encouraged by government agricultural policies. Cultivation area, production and yields of some cash crops have significantly increased since 1964/65. Nepal's livestock population is one of the highest in Asia and nearly every rural household keeps domestic animals resulting in widespread and serious problems of livestock overgrazing. The importance of agricultural habitats for Nepal birds is reviewed: $21 \%$ of bird species recorded in Nepal utilizes agricultural habitats for foraging at some season. The many ecological benefits of birds to agriculture and the damage caused by birds to agriculture are described: the former far outweigh the latter. Changes in agricultural practices (including changes in crops and crop production, impacts of livestock overgrazing) are having major and far-reaching impacts on natural habitats - grasslands wetlands and forests and their bird species; these changes and impacts are detailed and analysed. The increasing use of pesticides in Nepal, which is especially high on vegetable cash crops, the serious impacts of pesticides on birds and the environment and alternatives to pesticides are reviewed. Fertilizer use in Nepal and the damaging impacts of fertilizer over-use on birds and the environment are also reviewed. Recommendations to improve farming methods for the benefit of the environment are given. These include government measures to promote organic agriculture; government measures to expand the System of Rice Intensification and to encourage further use of Effective Microorganisms, both of which have significant benefits for environment, birds and farmers; field surveys to monitor bird populations and bird distribution on agricultural lands, and outreach and awareness-raising for farmers to apply best practice for sustainable environmentally friendly farming.
\end{abstract}

Key words: Agriculture, farming, birds, environment, conservation, impact, pesticides 
C. Inskipp and H.S. Baral / Our Nature (2010) 8: 270-312

\section{Introduction}

The State of the World's Birds report, launched at BirdLife International's 2008 World Conference, delivered the stark message that in much of the world, many bird species are in decline (BirdLife International, 2008a). These declines are taking place in both temperate and tropical regions, and in a variety of different habitats, including farmlands, forests and wetlands, alerting us to wider environmental problems. There are exceptions: some bird populations are stable and a few are increasing- in part a reflection of conservation efforts, but also because this relatively small number of species benefit from human activities and can thrive in altered habitats (BirdLife International, 2008a).

The report identifies many key global threats notably climate change, the intensification of agriculture and fishing, the spread of invasive species, and the loss of native forest (BirdLife International, 2008a).

Farmland is now considered the world's most widespread habitat (Van der Weijden, 2010). BirdLife International (2008a) considered that the expansion of agriculture, resulting in habitat destruction, is one of the greatest threats to the world's biodiversity. Intensification of farming practices, such as the loss of crop diversity, destruction of grasslands and excessive use of pesticides and fertilizers, has led to the degradation of agricultural and semi-natural habitats, and is also causing declines in biodiversity across huge areas. Overall, agriculture currently destroys and degrades more habitat than any other factor, according to BirdLife International (2008a).
In addition agricultural expansion and intensification is regarded as the main threat to globally threatened species, affecting $87 \%$ of all these species worldwide (Van der Weijden, 2010).

An analysis has been made of the combined data from a number of European national monitoring schemes of 124 of Europe's common birds, which took place over a 26-year period (1980-2006). These data showed that 56 species $(45 \%$ of those surveyed) had declined across 20 countries, with farmland birds doing particularly badly. Intensification of agriculture was found to be the major cause of farmland bird declines in Europe (BirdLife International, 2008b).

In Nepal there has been a considerable amount of work done on threatened birds, especially globally threatened species in the last 20 years. In contrast there has been very little monitoring of common bird species or of those habitually frequenting agricultural lands. Monitoring of farmland birds in Nepal started in 2007, but due to lack of sufficient funding, the work is limited to studies in the Lumbini farmlands Important Bird Area (IBA). In 2007, three transects were made in the IBA and these were regularly monitored. There is a plan to continue this bird monitoring programme during the winter of 2010 with up to five transects in Lumbini and possibly two in the Koshi area (Himalayan Nature, 2006).

Nepal studies on several vulture species illustrate the value of monitoring very well and indicated over $90 \%$ decreases in numbers from 1995 to 2009 (DNPWC et al.,2009). These studies have revealed 
seriously damaging impacts on vulture populations caused by the use of a chemical drug diclofenac to treat livestock in the Indian subcontinent. Diclofenac, which was introduced to the region in the 1990s, was one of the most widely distributed and used veterinary drugs. Farmers often referred to diclofenac as a magic drug because it was so effective. When vultures feed on livestock (mainly cows) that are treated with diclofenac this usually leads to their death in less than a week. The vultures' kidneys fail to excrete diclofenac and accumulation of the drug causes visceral gout which eventually kills the birds. The vultures have declined dramatically by feeding on dead livestock. For example, White-rumped Vulture Gyps bengalensis, once the most common vulture occurring up to $1000 \mathrm{~m}$ in Nepal, (Inskipp and Inskipp,1991), has declined by a catastrophic 90 to $95 \%$ within the last 15 years (Baral, 2008; Bird Conservation Nepal, 2009). Declines of White-rumped Vulture have been mirrored in other countries in its range and the species is now considered Critically Endangered globally (BirdLife International 2010). The Nepal studies also confirmed that the use of diclofenac caused the population crash (Shultz et al., 2004; Oaks et al., 2004). Slender-billed Vulture Gyps tenuirostris was formerly considered fairly common in Nepal up to 1525 m (Inskipp and Inskipp, 1991), but several surveys revealed its recent demise in the country e.g., Pandey and Gupta (2002); Giri et al. (2004) and Giri and GC (2005). The species has also been categorized as Critically Endangered globally by BirdLife International (2010). Both Egyptian Vulture Neophron percnopterus and Red-headed
Vulture Sarcogyps calvus were described as fairly common in Nepal by Inskipp and Inskipp (1991), but rapid declines in the region that were documented by Cuthbert et al. 2006) led to Egyptian Vulture being included as Endangered and Red-headed as Near-threatened on the globally threatened list.

Massive declines of two other vulture species have been recorded in Upper Mustang recently and both studies conclude that if ongoing declines are observed on a wider geographic scale, then the conservation status of these species should be reassessed.

A decrease of $84 \%$ of active nests of Himalayan Griffon Gyps himalayensis was recorded between 2002 and 2005 and was thought highly likely to be due to diclofenac poisoning (Acharya et al., 2009). The numbers of Lammergeier (Bearded Vulture) Gypaetus barbatus recorded per day decreased by $80 \%$ between 2002 and 2008 and although the cause is unknown, diclofenac is suspected. Nowadays the entire vulture group in Nepal seems to be facing problems.

The veterinary production of diclofenac was banned in Nepal in 2006 and efforts have been made to promote safe alternative drugs such as Meloxicam (DNPWC et al., 2009). Other conservation measures in the country include a breeding centre in Chitwan National Park, and the provision of safe food for vultures through an innovative concept of community managed vulture 'restaurants' (Baral, 2008; Bird Conservation Nepal undated b).Besides these programmes, education awareness and advocacy work are underway, mainly led by Bird Conservation Nepal and also by the 
C. Inskipp and H.S. Baral / Our Nature (2010) 8: 270-312

Nepal Trust for Nature Conservation and WWF Nepal. In 2009 a Vulture Conservation Action Plan was launched by government bodies in Nepal (DNPWC et al., 2009).

It has been widely recognized that current agricultural practices in Nepal pose threats to the natural environment. However, with the exception of the effects of diclofenac use on vultures, the potential impacts of agriculture on Nepal's birds have not been assessed until now.

\section{Agriculture in Nepal}

Nepal 's population was 8.5 million in 1952 , and had risen to an estimated 28.6 million in 2008 when it was increasing at $1.7 \%$ per year (World Bank, 2010). At this rate of increase, by 2011 the country' population will be almost 30 million. This sharp rise has resulted in greatly increased demands for food production.

Agriculture is the mainstay of the Nepalese economy, providing about a 33\% share to national GDP (National Plannning Commission, 2007). About $80 \%$ of the rural population aged over 15 is engaged in agriculture (Pandey et al., 2009). Nepal has $21 \%$ of its total land cultivable and this is exploited by two-thirds of Nepalese people for their livelihoods. Inadequate precipitation limits agricultural production, but only $32 \%$ of farmland is irrigated, despite government efforts and investment in agricultural development projects (Nepal Development Information Institute, 2006).

Rice, maize and wheat are the major crops in Nepal. Rice-based cropping systems, with wheat or maize as a secondary crop are predominant in the terai and middle hills, whereas in the high mountains maize, millet, barley and buckwheat are cultivated. Tea, cardamom, ginger and coffee are important cash crops of the middle hills. A wide range of fruits is grown: citrus in the middle hills, and tropical/subtropical fruits in the terai and middle hill valleys. Vegetable-growing in kitchen gardens is practiced at all elevations (Pandey et al., 2009) and has recently become an important cash crop.

Paddy is the most important crop in Nepal. It contributes more than $50 \%$ of the total calories required by the Nepalese people and paddy production covers more than $50 \%$ of the agricultural area (Basnet, 2008). A total of $3,680,839$ MT was produced in 2006/07. The large proportion of paddy is grown in the terai; $71-75 \%$ of paddy between $1997 / 98$ and 2006/07, for example. Maize and wheat are the other major cereal crops, with $1,819,926$ MT and $1,515,140$ MT produced respectively in $2006 / 07$. The majority of maize is produced in the hills and mountains. The terai produces most wheat and the proportion has increased significantly from 58\% in 1997/98 to $73 \% 2006 / 07$. Other cereal crops grown are millet and barley but their contribution to overall cereal production is small, $282,815 \mathrm{MT}$ and 26,580 MT, respectively in 2006/07 (CBS, 2007).

Despite changes in agricultural practices that have taken place throughout much of Nepal, agricultural development has been sluggish and, most importantly, has failed to keep pace with population growth (Maltsoglou and Taniguchi, 2004). The yield of major food crops in Nepal in recent years has been lower than in other South Asian countries (Pandey et al., 2009). Amgain and Timisina (2004) considered 
that improved varieties and improved soil and crop management were needed to improve rice and potato yields, while the adoption of already recommended technologies would improve wheat yields. However Pandey et al. (2009) concluded that improved access to and availability of agricultural inputs is key to improving yields.

\section{Changes in land holding and field sizes}

Land holding size per family has decreased as well as field sizes. During the 20 years between the 1981/82 and 2001/2002 census, the average national land holding size decreased by $30 \%$ from 1.13 ha to 0.79 ha. In the west of the country land holdings are even smaller, 0.44 ha in Achham, for example (CBS, 1994; 2007). Land holding sizes are continually decreasing; partly because of the way that land is inherited in Nepal-land is divided equally between sons. Another factor is that nowadays the government discourages the holding of larger land sizes that used to be a common feature of Nepal in the past.

As the most agriculturally suitable lands have already been brought under cultivation, the average density of population in one square $\mathrm{km}$ must have increased to a threshold level in almost all parts of Nepal, according to Bhurtel and Ali (2009). If the central hill districts, where Kathmandu is located, are excluded, then the highest population densities are in the Far western mountains and hills. In 1991, the average population density in one square $\mathrm{km}$ of arable land nationally was 879 , while in 2001, it increased to 1066. In 1991 in the Far-western mountain region, the population density $/ \mathrm{km}^{-1}$ was 1235 and increased to
1438 in 2001. Similarly, in the Far-western hills region population density $/ \mathrm{km}^{-1}$ increased from 1411 to 1695 (Bhurtel and Ali, 2009).

\section{Changes in crops and crop production Cereal production}

Wheat production increased by a massive $1163 \%$ between 1950/51 and 2006/07, although yields only rose by $125 \%$ during the period. There was also a large increase of $81 \%$ in paddy production between 1950/51 and 2003/04, although once again yield increase during the period was smaller $(50 \%)$. Both production and yields of paddy have decreased since 2003/04 (Ministry of Agriculture and Cooperatives a, b; CBS, 2007). Between 1950/51 and 2006/07 percentage production increases for wheat and paddy have been significantly higher than percentage increases in yields. Production rises can therefore have been very largely achieved by the increasing spread of agricultural lands and at the expense of forests, grasslands and wetlands. An assessment by Pandey et al. (2009) of 1994-2007 data for rice and maize based cropping systems also concluded that growth in yield of crops was very minimal in the terai, hill and mountain regions and that production increase had been achieved mainly through increases in area. The average yield of rice in Nepal $(2.68 \mathrm{~kg} / \mathrm{ha})$ was significantly below the world average of about $4.0 \mathrm{~kg} / \mathrm{ha}$ (Uprety, 2004). Only a $6 \%$ increase in yield of paddy was achieved between 1997/98 and 2006/07 (CBS, 2007). Uprety (2004) pointed out that low yields of rice in Nepal result from various factors such as older-generation seeds (most farmers have used their own seed for 
decades), low doses of chemical fertilizer, little use of improved cultivation practices, and less care for plant protection.

Recently, there has been a shift to the use of high yielding varieties (HYVs) of rice. However, access to these HYVs is usually limited and the varieties that are available often require the application of significant commercial fertilizers. This becomes a huge burden upon the poorer rice farmers who lack the finances to manage such inputs. Many farmers in Nepal therefore grow only traditional varieties of rice (TVE, 2004). The spread of HYVs and associated technologies has been very limited and concentrated in pockets of favourable irrigated areas (Joshi and Pandey, 2005).

The System of Rice Intensification (SRI) is a new method that has high potential to increase rice yields. It was first trialled in Nepal in 2002 and has only been used in relatively small areas to date, although its popularity is growing. The SRI method requires damp soils, but fields do not need to be flooded, so it is less waterdemanding, and no chemical pesticides or fertilizers are needed. This low input system has been shown to more than double rice yields where it has been trialled in Nepal (Uprety, 2004; ISIS, 2005; SRI Group, 2009). The large majority of paddy is still grown in the wet season as has happened traditionally, with only a small proportion grown in the dry winter season, presumably because of lack of sufficient irrigation water.

Maize, millet and barley are grown chiefly in the hills. Maize production has increased in most years since 1950/51 and overall by $120 \%$ by $2006 / 07$. However maize yields only increased by $16 \%$ during the period and have hardly changed in the last ten years. Millet production increased by the huge figure of $491 \%$ between 1950/51 and 1999/2000, but changed little in later years up to $2006 / 07$. Yields of millet have hardly altered since 1950/51. Barley production increased by $158 \%$ between $1950 / 51$ and $1995 / 96$ but then decreased by $36 \%$ by $2006 / 07$. Barley yields have also scarcely changed since 1950/51 (Ministry of Agriculture and Cooperatives b; CBS, 2007). Considering the low increase in maize yields and lack of yield increases in barley and millet since 1950/51, increases in production can again only be attributed to the concurrent replacement of forests, grasslands and wetlands by cultivation. According to Takahatake (2001) if hill regions are considered independently, all cereal crop yields have stagnated for the past 30 years and gains in production that have been made, have been due to increases of area under cultivation.

Various studies have documented that crop productivity in the hills has declined due to land degradation (Bohle and Adhikari, 1998; MoEST, 2006; Acharya and Kafle, 2009; Bhurtel and Ali, 2009). According to Ministry of Environment, Science and Technology data (MoESt, 2006) $28.24 \%$ of land in Nepal is degraded and $10 \%$ of this is poorly managed sloping agricultural terraces. During the last 20 years, Nepal has transformed from a net exporter to a net importer, partly as a result of land degradation, according to Cameron (1995). Conflict and frequent natural disasters have been other important factors. For example the 2008/2009 winter drought one of the worst in the country's history - 
destroyed crops across Nepal. Nationally wheat and barley production reduced by $14 \%$ and $17 \%$ respectively, while crop yields in some districts in Mid- and FarWestern Nepal dropped by more than half. Since the 1990s Nepal has been becoming steadily dependent on food imports and $41 \%$ of the population is now believed to be malnourished, according to the World Food Programme (2010).

\section{Cash crops}

As yields and production of cereal crops have fallen in the hills, nowadays many farmers are becoming more impoverished and, indeed, many cannot grow enough to feed their own families throughout the year using traditional methods. In some parts of the country, they are therefore shifting to cash crops.

Increases in cash crop cultivation have been promoted since the 1990s by government agricultural policies, which have highlighted the importance of growing cash crops so that farmers can earn money to help meet their food deficits (Takahatake, 2001).

Funding to promote cash crop development has been provided by the Asian Development Bank and the World Bank (Anon., 2000a, b). However, an analysis of cash cropping made by Brown and Kennedy (2005) found that the costs and benefits of developing markets have been unevenly distributed, with small holders unable to capitalize on market opportunities and wealthier farmers engaging in input-intensive cash cropping. Brown and Kennedy (2005) concluded that commercial vegetable production had limited short term impact on poverty alleviation, although they considered that production was likely to continue increasing.

Cultivation areas and production of some cash crops sharply increased between $1964 / 64$ and 2006/07. The cultivation areas of sugar cane and oil seed increased by $611 \%$ and $71 \%$ respectively during the period, for example. Yields also increased but at a much lower rate: by $190 \%$ and $56 \%$ respectively (Ministry of Agriculture and Cooperatives data a,c; CBS, 2007).

Another cash crop, potato, is the fourth most important food crop in the country after rice, maize and wheat; its cultivation extends from the terai to the northern mountains. Yet Nepal has one of the lowest national yield averages globally (Campilan et al., 2006). Between 1964/65 and 2006/07, the cultivation area increased by as much as $429 \%$, but yields only increased by $28 \%$ (Ministry of Agriculture and Cooperatives data a,c; CBS, 2007). Diseases caused by using low quality seed and poor crop management, are a major limiting factor in improving productivity (Campilan et al.2006).

In the relatively short period of 15 years between 1991/92 and 2006/07 the area under vegetable cultivation increased by $36 \%$. Production of vegetables increased even more (by 104\%), resulting in sharp increases in yields (49\%) and indicating that vegetable farming methods have intensified significantly during the period (Ministry of Agriculture and Cooperatives, Government of Nepal d; CBS, 2007).

Urban populations in Nepal have been booming in recent years and have been driving agricultural changes. The number of farmers has decreased while increased 
numbers of residents in urban areas need to buy most, if not all of their own food. One important change is that the rising urban Nepalese population is demanding more cash crop produce. Cultivation of these cash crops has been able to develop in farming areas close to national highways, which provide good links to towns and cities where farm produce is marketed. This has led to the rice-wheat cropping system in the central mid hills partly changing to ricevegetable cropping systems (Atreya, 2008). The vegetables produced are sold at relatively high prices in Kathmandu and other nearby towns (Shrestha and Neupane, 2002). Farmers in Chitwan are greatly attracted to grow cash crops of vegetables and fruits instead of paddy and wheat, as Chitwan has relatively good road links with Kathmandu (H. S. Baral pers. obs.). In addition, management of Chitwan National Park, which is situated in the central lowlands, has recently started to encourage local people to replace rice and wheat, which are highly favoured by marauding Asian Elephant Elephas maximus and Greater One-horned Rhinoceros Rhinoceros unicornis, by cash crops (TAL Program 2009, WWF Annual Report 2007, 2008). A case study of cash cropping in Ilam district in east Nepal found that recent road surfacing gave farmers better access to markets for their cash crops. Ilam district's geographical proximity to the terai and the important Nepalese trading centre of Birtamod, as well as to Indian cities was found to be another reason for the expansion of cash cropping there (Takahatake, 2001). Paddy fields in the Koshi area in the southeast terai have been widely replaced by vegetables, sunflowers and other non- traditional crops since the 1990s (H. S. Baral and C. Inskipp, pers. obs.).

Pandey et al. (2009) pointed out that during the 1995-2004 period, despite their smaller harvested area, the contribution of vegetables to gross production value was remarkable in the terai, hills and mountain regions $(24 \%, 24 \%$ and $21 \%$ respectively in 2003). This implied that growing vegetable crops was one of the most valuable sources of farm income. The importance of vegetables is particularly high in the hill and mountain regions, as their yield of major food crops is significantly lower in these regions (Pandey et al., 2009).

\section{Livestock overgrazing}

Nearly every rural household keeps domestic animals (Regmi, 1994). In relation to the amount of land per person, the livestock population in Nepal is one of the highest in Asia. Although the productivity of livestock is very low, livestock products are an important source of supplementary income for more than $80 \%$ of the country's farmers (Paudel et al., 2009). An analysis of livestock data between 1990/91 and 2006/07 revealed that the most noticeable changes during the period have been the marked increases of buffalo and goat populations, $43 \%$ and $46 \%$ respectively. The cattle population also increased, but by the smaller figure of $12 \%$ and since 1997/98 there has been little recorded change. Numbers of sheep decreased by $10 \%$ between 1990/91 and 2006/07; however, their population is much lower than that for cattle, buffalo and goat. Poultry numbers have increased almost annually during the period, and by the high proportion of $35 \%$ overall. 
Grazing is a year-round threat to many of the protected areas in the terai, whereas it is a seasonal threat to the high elevation pastures of the Himalayas. In either case overgrazing is prevalent. The level of livestock grazing is one of the most serious threats to the ecological integrity of the mid-hill and highland protected areas (HMGN/MFSC, 2002).

The impacts of livestock overgrazing on forests, grasslands and wetlands and their bird communities is included in separate habitat sections below. In addition, heavy grazing and browsing promote the spread of an invasive alien creeper Mikania micrantha which is a particularly dangerous threat as it proliferates in a wide range of habitatsforests, grasslands, wetlands and agricultural lands (Siwakoti, 2007). The weed cannot tolerate shade and hence fails to penetrate undisturbed natural forest areas (Sankaran, undated). Mikania is now a major, though relatively new threat to Nepal's ecosystems, including many bird species. Although it was first collected in the country in Ilam district in 1963 (Tiwari et al., 2005), it only became a problem in recent years. The creeper has now invaded tropical and subtropical ecosystems of Nepal from Mechi to Lumbini zones (Ilam/Jhapa to Kapilvastu districts) (Siwakoti, 2007).

Growth of young plants is extremely fast ( $8-9 \mathrm{~cm}$ in 24 hours). A single stalk can produce $20,000-40,000$ mature seeds in one season. Using trees as a support, the weed rapidly forms a dense cover of entangled leafy stems. It smothers, chokes and pulls over other plants, causing a significant reduction in their growth (Sankaran, undated). Mikania significantly reduces plant biodiversity by swamping vegetation and out-competing native plants (Siwakoti, 2007). As it quickly covers the entire forest floor, the vine makes it impossible for bird species to feed on the ground. Terrestrial feeding species like thrushes and pipits, as well as several other species such as babblers that require open forest floors, with or without decaying leaves, are all affected (Baral, 2002).

Mikania has had a devastating effect on Koshi Tappu Willdife Reserve, where within five years; it has engulfed a large chunk of the reserve's marshes and terrestrial habitats (Baral, 2002). Preliminary bird ringing observations indicate that the population of Acrocephalus warblers wintering at Koshi has declined (VAN Baral pers. obs). One possible factor could be the spread of Mikania over the entire area of shrubs and bushes in Koshi Tappu.

The weed is also a grave threat to some bird species and environment in Chitwan National Park (Baral, 2002; Sapkota, 2007; Siwakoti, 2007). On a recent visit to Chitwan, Slender-billed Babbler Turdoides longirostris and Rufous-rumped Grassbird Graminicola bengalensis were noted on a newly formed grassland. Lower numbers of these birds were recorded within the park, indicating that specialist grassland birds like these are also facing severe threats from Mikania (VAN Baral pers. obs.).

The western terai is still free from Mikania. It has been suggested that regular field monitoring is necessary for the early detection of introduction of Mikania followed by a rapid response to remove the species (Siwakoti, 2007). 
Work led by the Nepal Trust for Nature Conservation and the Zoological Society of London is underway to understand the extent of the problems caused by Mikania and possible measures to minimize its effects on native wildlife.

\section{Agriculture and climate change in Nepal}

The impacts of climate change on Nepal's birds are currently poorly understood, but are likely to be significant (Baral and Inskipp, 2004). Agriculture has been shown to produce significant effects on climate change, primarily through the production and release of the greenhouse gases carbon dioxide, methane and nitrous oxide (Karki, 2008). Agriculture contributes to greenhouse gases in four main ways: carbon dioxide linked to deforestation to make way for agricultural lands; methane releases from rice cultivation, methane releases from enteric fermentation in livestock, and nitrous oxide releases from fertilizers and manures (Karki, 2008). According to Smith et al. (2007), agriculture accounts for 52 and $84 \%$ of global anthropogenic methane and nitrous oxide emissions, both of which are powerful greenhouse gases.

Studies in Nepal showed that average seasonal emission of methane from rain-fed paddy fields was $28 \mathrm{~kg} / \mathrm{ha} /$ season. Figures for Thailand and India were much higher, 49 and $45 \mathrm{~kg} / \mathrm{ha} /$ season respectively, and these may be accounted for by higher use of chemical fertilizer and better irrigation (Malla, 2008).

Importance of agricultural habitats for Nepal birds

The availability of invertebrates, small mammals, amphibians, spilt grain and weed seeds in cultivation provide food for a diverse range of Nepal species. A total of 184 species, $21 \%$ of the total recorded utilizing agricultural habitats for foraging at some time. A smaller number of these species breed in agricultural lands and associated micro-habitats. Agricultural areas are unprotected but still form valuable habitats for many species, including some which infrequently occur in protected areas, notably the globally threatened Sarus Crane Grus antigone.

Cultivation forms the chief habitat for a relatively small number of bird species, however. These include the Sarus Crane which is chiefly found in cultivated fields in the terai, which it utilizes for both foraging and breeding. A recent study found that $70 \%$ of nests were on paddy field bunds and $30 \%$ on marshy wetland bunds (Paudel, 2009b). The Lumbini farmlands Important Bird Area is the only area in Nepal where the species regularly breeds. In most areas where they occur in Nepal the globally threatened Indian Spotted Eagle Aquila hastata and Lesser Adjutant Leptoptilos jaVanicus often nest in trees in cultivated areas. Indeed, with the exception of Chitwan National Park and Sukla Phanta Wildife Reserve, all nests of Lesser Adjutant in the country are in private cultivated lands or at the edge of community forests. Cultivation is also an important foraging habitat for Lesser Adjutant. In sugarcane plantations, for example at Koshi and Chitwan, large numbers of buntings, including Yellow-breasted Bunting Emberiza aureola, were recorded in the 1980s and 1990s, although numbers are much reduced nowadays. Other Nepal species (not counting vagrants) which 
mainly occur in cultivated areas are Black Francolin Francolinus francolinus, Grey Francolin F. pondicerianus, Common Quail Coturnix coturnix, Black-breasted Quail $C$. coromandelica, Indian Pond Heron Ardeola grayii, Cattle Egret Bubulcus ibis, Redwattled Lapwing Vanellus indicus, Greyheaded Lapwing $V$. cinereus, Red-necked Falcon Falco chicquera, Bengal Bushlark Mirafra assamica, Ashy-crowned Finch Lark Eremopterix grisea, Spotted Dove Streptopelia chinensis, Crested Lark Galerida cristata, Paddyfield Pipit Anthus rufulus, Common Stonechat Saxicola torquata, Pied Bushchat S. caprata, Zitting Cisticola Cisticola juncidis, Common Babbler Turdoides caudatus, Large Grey Babbler T. malcolmi, Jungle Babbler T. striatus, Asian Pied Starling Sturnus contra, Baya Weaver Ploceus philippinus, Pine Bunting Emberiza leucocephalos, Little Bunting E. pusilla, Black-headed Bunting E. melanocephala, and Crested Bunting Melophus lathami. All the above species are Nepal residents, except for Common Quail, which is a summer visitor, and Grey-headed Lapwing, Pine, Little and Black-headed Buntings which are winter visitors and/or passage migrants. Very few of these species breed in the fields: the ones that do are Common Quail, Red-wattled Lapwing, the two larks, Paddyfield Pipit and Zitting Cisticola. Most of the other species that breed in cultivation nest in habitats at cultivation.edges or strips between the fields.

Flooded paddy fields and paddy stubbles are important feeding habitats for many wetland birds, including the nearthreatened Black-headed Ibis Threskiornis melanocephalus, also egrets, some storks such as Lesser Adjutant, Asian Openbill Anastomus oscitans, Woolly-necked Stork Ciconia. episcopus, and Black Stork $C$. nigra, Indian Pond Heron, White-breasted Waterhen Amaurornis phoenicurus, Ruddybreasted Crake Porzana fusca, snipe Gallinago spp, a number of duck and wader species, as well as many species of doves, larks, pipits, wagtails, munias, finches and buntiings. Some species feed on standing crops of paddy and other cereals, such as Rose-ringed Parakeet Psittacula krameri, Baya Weaver, finches and buntings.

Cultivated fields in hill and mountain areas provide valuable feeding areas for some pigeon and dove species, including Oriental Turtle Dove Streptopelia orientalis and Snow Pigeon Columba leuconota, as well as some species of pipits and larks. Hill and mountain grasslands are utilized as feeding areas by a small number of species, including Himalayan Monal Lophophorus impejanus, Red-billed Chough Pyrrhocorax pyrrhocorax, Yellow-billed Chough $P$. graculus, thrushes, pipits, larks and rosefinches.

Although the chief habitats of the globally threatened Bengal Florican Houbaropsis bengalensis, and Lesser Florican Sypheotides indica (now a very rare visitor to Nepal) are lowland grasslands, during the short periods when these habitats are unavailable due to annual cutting and burning, they have sometimes been recorded in nearby cultivation.

For numerous species the farmland areas that are valuable for birds are the uncultivated field corners and strips between fields. These areas are often vegetated with rough grass and other herbaceous plants that form good foraging 
and nesting habitats for Black and Grey Francolins, buttonquails Turnix spp., larks, pipits and finches, and also with bushes that can support a wide range of species, such as chats, shrikes and warblers. Sarus Cranes in the Lumbini area have been found to be quite dependent on strips and patches of land between paddies for nesting and river banks for roosting (Paudel, $2009 \mathrm{a}, \mathrm{b}$ ).

In the Lumbini farmlands large native trees are important features within the agricultural landscape, providing roosting and nesting sites for birds, as well as valuable wildlife corridors. A pair of the globally threatened Indian Spotted Eagle was found to be using a Kapok tree Bombax ceiba in the area (Hanlon and Giri, 2007) and nested there for several years (VAN Baral pers.obs.). Groves of trees and isolated trees in farmland habitats are useful nesting sites for many species including White-rumped Vulture, Red-necked Falcon, Spotted Owlet Athene brama, doves Streptopelia spp, and mynas Acridotheres spp.

Field size may be an important factor in the provision of feeding and nesting opportunities. For example, the farmed landscape of Lumbini still consists of small cultivated fields bordered by grass bunds that provide a large area of valuable "edge effect' vegetation, important for many species. They also provide cover, and a safe area for overwintering invertebrates, as well as invertebrate and seed food sources for birds (Hanlon and Giri, 2007).

Many bird species require two or more habitat types close together, especially during the breeding season when they have a restricted range. Some species prefer edges or a mix of farmland and natural habitat, spending parts of their life cycle in a natural habitat, but relying on nearby farmland for food, water or breeding. For example, Lesser Adjutant regularly breeds in groves but nearby flooded paddy fields are often important food sources. Birds of prey such as Eurasian Sparrowhawk Accipiter nisus breed in woods and hunt birds on adjacent farmland (Van der Weijen, 2010).

Farmland can provide birds with valuable shelter and water. Many bird species need some form of shelter from land and aerial predators when feeding, resting or breeding. Flooded paddy fields can provide security for birds from ground predators, for instance (Van der Weijen, 2010).

\section{Ecological benefits of birds to agriculture}

Many birds are useful to farmers for:

- the dispersal of seeds;

- the control of snakes and harmful pests in crops;

- cleaning up the environment by acting as natural scavengers;

- pollinating crops and plantation trees;

- helping to ensure that farming is sustainable by acting as indicators

- the health of the ecological system,

- their fascination owing to their sweet and melodious songs and their courtship dances Singh (2007).

Van der Weijen (2010) described some additional ecosystem services that birds offer to farmers including:

Ducks in winter-flooded paddy fields can help to control weeds by eating their seeds. This has the potential of reducing herbicide use and associated pollution.

* Straw left on paddy fields after harvest can be an obstacle to paddy cultivation the 
following spring, but dabbling ducks can substantially enhance straw decomposition. Winter flooding facilitates this process. This can also potentially enhance nitrogen supply to subsequent crops, allowing the producer to economize on fertilizer use.

\section{Damage by birds to agriculture}

Van der Weijen (2010) described damage that birds can cause to farming; this can be serious:

* Herbivorous birds can eat substantial quantities of seeds and fruits in crops quite rapidly, while foraging in large flocks, for example all parakeet Psittacula spp. and Baya Weaver in Nepal,. In the hills Grey Treepie Dendrocitta formosae raid maize crops, but not to the extent those villagers regard this as a problem.

* Some raptor species prey on small livestock, mainly free-ranging chickens.

* Foraging birds can trample the soil and spoil the seedbeds of crops (Van der Weijen, 2010).

Impacts of agricultural practices on birds Changes in agricultural practices

In areas where rice and wheat cultivation have been replaced by cash crops bird populations are likely to have been seriously impacted. Many species, especially those which often feed in flooded paddy fields and paddy stubbles, must have lost significant areas of habitat. A study of Sarus Cranes at Lumbini showed that feeding and roosting grounds were reduced and disturbed due to watermelon farming on riverbanks, and by sugarcane and banana farming in farmland (Paudel, 2009b). High pesticide use on cash crops and, especially on vegetables and potatoes, may well be causing sharp declines bird populations and diversity. However, no studies have been made to date on the impacts of the shift to cash crops on birds in Nepal.

It is possible that the use of HYVs will become more widespread than at present and the associated high doses of chemical fertilizer that are required by this method may be detrimental to birds, see Fertilizer Use section below.

If the new System of Rice Intensification (SRI) (see Cereal Production section above) becomes widespread the replacement of flooded fields by damp soils will be detrimental to many wetland species, such as ducks that forage in shallow waters. However, a large number of bird species, including some large wading birds such as Lesser Adjutant, other stork species, Blackheaded Ibis, and numerous waders should find the damp soils good feeding habitat. The absence of use of chemical pesticides and fertilizers in SRI will certainly benefit birds. No studies have so far been made comparing bird populations and diversity in fields under SRI and those using HYVs and traditional methods.

The effects on birds of fertilizer use and of pesticides on some other crops may also be significant and are discussed in sections on Pesticide use and Fertilizer use below. However, there are no studies to illustrate these impacts in Nepal to date.

\section{Impacts of habitat changes}

The spread of agriculture has lead to the extensive replacement of grasslands, wetlands and forests, which are all important bird habitats. As human population has increased so have the numbers of homes and other buildings, and 
these have often been constructed on agricultural land. For example, in the Kathmandu valley large areas of formerly productive fields have been urbanized, especially since the 1970s. In this way urbanization has led to further losses of natural habitats to replace lost agricultural lands. The structure of hill terraces used for cultivation remains unchanged, although terraces are abandoned if the land has become degraded and is no longer suitable for cultivation.

The continuing trend for field sizes to become smaller could benefit birds. As the edges and strips between fields will increase as fields become smaller they should produce additional habitats for some species that feed or nest on the ground. However, the effect of field sizes on bird populations has not been studied.

\section{Grasslands}

\section{Importance of grasslands for birds}

Lowland grasslands cover a very small area in Nepal and are mainly confined to protected areas. In total, lowland grasslands cover less than $500 \mathrm{~km}^{2}$, which amounts to less than $2 \%$ of the country's protected land. Even so this habitat is vitally important for a significant number of globally and nearthreatened species, as well as specialists. Out of 35 globally threatened birds recorded in Nepal (BirdLife International, 2010), as many as 18 species, $51 \%$, utilize lowland grasslands in some ways, see table 1 , as well as four near-threatened species, see table 2 (Baral, 2001; BirdLife International, 2010).

Recently, a new subspecies of Rufous-vented Prinia Prina burnesii nepalicola was described from the grasslands of Koshi Tappu (Baral et al., 2007; Baral et al., 2008). The species seems to form a missing link between the currently known two subspecies of this bird found in Pakistan and India. The birds reported from Koshi seem to show characters more similar to the eastern subspecies found in Assam and are currently known only from Koshi Tappu. The habitat is in an extremely small area and subject to annual flooding and burning. Protection of grasslands in various islands of Koshi Tappu is therefore vital for conserving this subspecies.

The lowland grasslands at Sukla Phanta Wildlife Reserve are by far the most important in Nepal, supporting as many as 18 globally threatened species (Baral and Inskipp, 2009). Other important lowland grasslands for birds lie in Chitwan National Park and Koshi Tappu Wildlife Reserve, with relatively smaller areas in Bardia National Park. All these protected areas have been categorized as Important Bird Areas, partly because of the value of their grasslands for birds (Baral and Inskipp, 2005).

Hill and mountain grasslands that lie in the subtropical and temperate zones, and probably some in the subalpine zone, were created by forest clearance that in many cases took place a very long time ago. These grasslands are very poor in bird diversity.

Two globally threatened species, Cheer Pheasant Catreus wallichii and Wood Snipe Gallinago nemoricola, as well as Himalayan Monal, Nepal's national bird, utilize grasslands in the temperate and subalpine zones. Other Galliformes that frequent high altitude grasslands at some time of the year are: Tibetan Snowcock Tetraogallus tibetanus, Himalayan 
C. Inskipp and H.S. Baral / Our Nature (2010) 8: 270-312

Table 1. Globally threatened species recorded in Nepal

\begin{tabular}{|c|c|c|}
\hline Species & $\begin{array}{l}\text { Globally threatened } \\
\text { status }\end{array}$ & Habitat \\
\hline $\begin{array}{l}\text { Swamp Francolin } \\
\text { Francolinus gularis }\end{array}$ & $\mathrm{VU}$ & Tall wet grassland and marshes \\
\hline $\begin{array}{l}\text { Cheer Pheasant } \\
\text { Catreus wallichii }\end{array}$ & VU & Steep craggy slopes with scrub, secondary growth \\
\hline $\begin{array}{l}\text { Pink-headed Duck } \\
\text { Rhodonessa caryophyllacea }\end{array}$ & $\begin{array}{l}\text { CR (Extirpated from } \\
\text { Nepal) }\end{array}$ & Pools and marshes in forest \\
\hline Baikal Teal Anas formosa & VU & Large rivers \\
\hline$\overline{\text { Baer's Pochard Aythya baeri }}$ & EN & Large rivers and lakes \\
\hline $\begin{array}{l}\text { Rufous-necked Hornbill } \\
\text { Aceros nipalensis }\end{array}$ & $\begin{array}{l}\text { VU (Extirpated from } \\
\text { Nepal) }\end{array}$ & Subtropical broadleaved forest with large trees \\
\hline $\begin{array}{l}\text { Great Slaty Woodpecker } \\
\text { Mulleripicus pulverulentus }\end{array}$ & VU & Mature sal forests \\
\hline Sarus Crane Grus antigone & VU & Cultivation and heavily grazed grasslands \\
\hline $\begin{array}{l}\text { Black-necked Crane } \\
\text { Grus nigricollis }\end{array}$ & VU & Upland marshes and fallow fields \\
\hline $\begin{array}{l}\text { Bengal Florican } \\
\text { Houbaropsis bengalensis }\end{array}$ & $\mathrm{CR}$ & Chiefly tall grasslands, rarely in cultivation \\
\hline $\begin{array}{l}\text { Lesser Florican } \\
\text { Sypheotides indica }\end{array}$ & EN & Chiefly grasslands, rarely in cultivation \\
\hline $\begin{array}{l}\text { Wood Snipe } \\
\text { Gallinago nemoricola }\end{array}$ & VU & $\begin{array}{l}\text { Breeds in alpine meadows and dwarf scrub; } \\
\text { winters in forest marshes }\end{array}$ \\
\hline $\begin{array}{l}\text { Indian Skimmer } \\
\text { Rynchops albicollis }\end{array}$ & VU & Large rivers \\
\hline $\begin{array}{l}\text { Pallas's Fish Eagle } \\
\text { Haliaeetus leucoryphus }\end{array}$ & VU & Large rivers and lakes \\
\hline $\begin{array}{l}\text { Egyptian Vulture } \\
\text { Neophron percnopterus }\end{array}$ & EN & Open country around habitation \\
\hline $\begin{array}{l}\text { White-rumped Vulture } \\
\text { Gyps bengalensis }\end{array}$ & $\mathrm{CR}$ & Around habitation \\
\hline $\begin{array}{l}\text { Slender-billed Vulture } \\
\text { Gyps tenuirostris }\end{array}$ & CR & Around habitation \\
\hline $\begin{array}{l}\text { Red-headed Vulture } \\
\text { Sarcogyps calvus }\end{array}$ & $\mathrm{CR}$ & Open country and well-wooded hills \\
\hline $\begin{array}{l}\text { Indian Spotted Eagle } \\
\text { Aquila hastata } \\
\end{array}$ & VU & Wooded areas, open fields and grasslands \\
\hline $\begin{array}{l}\text { Greater Spotted Eagle } \\
\text { Aquila clanga }\end{array}$ & VU & Large rivers and lakes, wooded areas near water \\
\hline $\begin{array}{l}\text { Imperial Eagle } \\
\text { Aquila heliaca }\end{array}$ & VU & Large rivers and lakes \\
\hline $\begin{array}{l}\text { Lesser Kestrel } \\
\text { Falco naumanni }\end{array}$ & VU & Open country \\
\hline $\begin{array}{l}\text { Saker Falcon } \\
\text { Falco cherrug }\end{array}$ & EN & Semi-desert in hills and mountains \\
\hline $\begin{array}{l}\text { White-bellied Heron } \\
\text { Ardea insignis }\end{array}$ & $\begin{array}{l}\text { CR (Extirpated from } \\
\text { Nepal) }\end{array}$ & Rivers in broadleaved foothill forests \\
\hline
\end{tabular}


Table 1-Contd....

\section{Inskipp and H.S. Baral / Our Nature (2010) 8: 270-312}

\begin{tabular}{lll}
\hline $\begin{array}{l}\text { Lesser Adjutant } \\
\text { Leptoptilos jaVanicus }\end{array}$ & VU & Marshes, pools and wet fields \\
\hline $\begin{array}{l}\text { Greater Adjutant } \\
\text { Leptoptilos dubius }\end{array}$ & EN & Marshes \\
\hline $\begin{array}{l}\text { Kashmir Flycatcher } \\
\text { Ficedula subrubra }\end{array}$ & VU & Open broadleaved forest \\
\hline $\begin{array}{l}\text { Hodgson's Bushchat } \\
\text { Saxicola insignis }\end{array}$ & VU & Grassland and tall grasses and reeds along rivers \\
$\begin{array}{l}\text { Grey-crowned Prinia } \\
\text { Prinia cinereocapilla }\end{array}$ & VU & Grassland in forest clearings and at forest edges; \\
\hline $\begin{array}{l}\text { Bristled Grassbird } \\
\text { Chaetornis striatus }\end{array}$ & VU & Short grassland with scattered bushes \\
\hline $\begin{array}{l}\text { Jerdon's Babbler } \\
\text { Chrysomma altirostre }\end{array}$ & VU & Reedbeds and tall grassland \\
\hline $\begin{array}{l}\text { Slender-billed Babbler } \\
\text { Turdoides longirostris }\end{array}$ & VU & Tall grassland and reeds \\
\hline $\begin{array}{l}\text { Black-breasted Parrotbill } \\
\text { Paradoxornis flavirostris }\end{array}$ & VU (Extirpated from & Dense thickets of reeds, high grasses and bamboo \\
\hline $\begin{array}{l}\text { Finn's Weaver } \\
\text { Ploceus megarhynchus }\end{array}$ & Nepal) & VU \\
$\begin{array}{l}\text { Yellow-breasted Bunting } \\
\text { Emberiza aureola }\end{array}$ & VU & Grasslands and cultivation \\
\hline
\end{tabular}

Table 2. Near-threatened species in Nepal

\begin{tabular}{ll}
\hline Species & Habitat \\
\hline Satyr Tragopan Tragopan satyra & $\begin{array}{l}\text { Moist broadleaved and coniferous forest with dense } \\
\text { undergrowth }\end{array}$ \\
\hline Falcated Duck Anas falcata & Lakes and large rivers \\
\hline Ferruginous Pochard Aythya nyroca & Lakes and large rivers \\
\hline Painted Stork Mycteria leucocephala & Marshes and lakes \\
\hline Black-necked Stork Ephippiorhynchus asiaticus & Marshes and large rivers \\
\hline Black-headed Ibis Threskiornis melanocephalus & Flooded fields, marshes, rivers and pools \\
\hline Spot-billed Pelican Pelecanus philippensis & Large rivers \\
\hline Darter Anhinga melanogaster & Lakes, pools and slow-moving rivers \\
\hline Laggar Falcon Falco jugger & Open country \\
\hline Lesser Fish Eagle Ichthyophaga humilis & Forested streams and lakes \\
\hline Grey-headed Fish Eagle Ichthyophaga ichthyaetus & Slow-running waters and lakes in wooded country \\
\hline Cinereous Vulture Aegypius monachus & Open country \\
\hline Pallid Harrier Circus macrourus & Open grassland and cultivation \\
\hline Black-tailed Godwit Limosa limosa & $\begin{array}{l}\text { Banks and shallow waters of lakes and slow-moving } \\
\text { rivers }\end{array}$ \\
\hline Eurasian Curlew Numenius arquata & Banks of rivers and lakes, grassy areas \\
\hline Black-bellied Tern Sterna acuticauda & Marshes, lakes and rivers \\
\hline Yellow-rumped Honeyguide Indicator xanthonotus & Near Giant Rock Bee nests on cliffs and adjacent forest \\
\hline Great Hornbill Buceros bicornis & Mature broadleaved forest with fruiting trees \\
\hline Blyth's Kingfisher Alcedo hercules & Streams in dense forest \\
\hline Rufous-vented Prinia Prinia burnesii & Tall grasslands \\
\hline
\end{tabular}


Table 2 - Contd....

\begin{tabular}{ll}
\hline Rufous-rumped Grassbird Graminicola bengalensis & Tall grass and reeds \\
\hline Tytler's Leaf Warbler Phylloscopus tytleri & $\begin{array}{l}\text { Oak/rhododendron forests and shrubberies at forest } \\
\text { edges }\end{array}$ \\
\hline Rufous-throated Wren-babbler Spelaeornis caudatus & Mossy rocks and ferns in dense broadleaved forest \\
\hline Blackish-breasted Babbler Sphenocichla humei & Dense streamside vegetation in moist broadleaved fores1 \\
\hline
\end{tabular}

Snowcock T. himalayensis, Himalayan Monal, Snow Partridge Lerwa lerwa, Tibetan Partridge Perdix hodgsoniae and Chukar Partridge Alectoris chukar. Passerine species which habitually frequent hill and mountain grasslands include Redbilled Chough, Yellow-billed Chough, larks, pipits and finches.

\section{Impacts of agriculture on grasslands Lowland grasslands}

Large-scale conversion of natural lowland grasslands into cropland has taken place throughout the Indo-Gangetic Plain including Nepal (BirdLife International, undated). This conversion took place in Nepal particularly since the malaria eradication programme in the mid-1950s (Peet, 1997). Today, remaining lowland grasslands are much reduced in area and very fragmented. Almost all now lie within protected areas (Baral and Inskipp, 2005).

For generations, lowland grasslands have been widely exploited by local people for their daily use and this tradition continues. Grasslands provide them with grass for thatching roofs and weaving mats (Baral, 2001). Grass is vital to feed their livestock and there is a large demand for it (BirdLife International, undated; Sharma and Shaw, 1997).

The Department of National Parks and Wildlife Conservation in Nepal has had to strike a balance between the conservation needs of protected areas and the immediate survival needs of people living adjacent to parks and reserves. Permission to harvest grass is a compromise with local people. The Chitwan park authority allows local people to cut grass for about ten days in winter, for example (Baral, 2001).

Annual lowland grass harvesting has the beneficial effect of impeding succession to woodland, but over-harvesting damages the habitat and creates disturbance (BirdLife International, undated). During the grasscutting season, $95 \%$ of grassland is believed to be disturbed in Nepal's lowland protected areas (Ram Prit Yadav pers. comm. in Baral, 2001). In Chitwan National Park as many as 70,000 local people are estimated to enter the park annually to cut grass (BirdLife International, undated).

Grass-cutting in summer is largely illegal. However, as grass is such a useful item for local people and because of the lack of tall grassland outside protected areas, illegal cutting and grazing continue around all protected areas (Baral, 2001). Grazing by livestock is by far the greatest threat to grasslands in protected areas and is illegal. Controlling the illegal grazing and cutting activities has been a difficult task for park managers in Nepal (Baral, 2001).

At Sukla Phanta, with the exception of the main phanta, over-grazing by domestic livestock, fodder collection and associated human disturbance are degrading the grasslands, notably those lying close to human settlements (Baral, 1997; Baral, 2000). Grassland sites in Chitwan occur close to the park's boundary and to villages 
and so face enormous pressure from grazing and illegal cutting (Baral, 2001). In addition, overgrazing and fodder collection is a major problem at Koshi Tappu Wildlife Reserve where large numbers of livestock have caused severe degradation (BirdLife International, undated). Large parts of the reserve are devoid of tall grassland as a result (Baral, 2001).

After the grasses have been cut in protected areas, mainly from January to March, extensive areas of grassland are set on fire by local villagers to enhance the growth of fresh grass shoots. Indeed, almost all grasslands in lowland Nepal are burnt once a year at some time between December and May (Baral, 2001). Although not much is known about the history of fire in lowland grasslands, it is thought that fire has been a formative influence either as an anthropogenic or natural phenomenon (Bell and Oliver, 1992). At present, fires seem essential to maintain the grassland ecosystems in protected areas (Baral, 2001). The initial effects of a fire are that the grassland becomes more open and the grassland height decreases on average by two-thirds (Baral, 2001).

\section{Hill and mountain grasslands}

In the hills and mountains grasslands have been maintained by overgrazing by livestock which has prevented the regeneration of the original forest. According to Ministry of Environment, Science and Technology data, $37 \%$ of Nepal's degraded land comprises pastures and rangelands which have been overgrazed (MoEST, 2006).

\section{Impacts of agriculture on grassland birds}

The drastic reduction in the area of lowland grasslands must have directly impacted on populations of birds that utilize this habitat type. Today, outside protected areas there are no significant remaining grassland areas that are capable of supporting threatened birds. Almost all these unprotected grasslands are intensively grazed by domestic livestock all year round and face other human pressures, notably overwhelming disturbance (Baral, 2001). As a result of serious threats to lowland grasslands that arise chiefly from agriculture, 17 bird species that depend on grasslands were considered at risk nationally, $14 \%$ of the total threatened (Baral and Inskipp, 2004).

A detailed study of Nepal's lowland grasslands in Chitwan National Park and Sukla Phanta Wildlife Reserve revealed that grazing, burning and grass height have significantly influenced the structure of bird communities (Baral, 2001).

Cutting, burning and cattle grazing all directly affect the height of grasses. Grass height was found to have an important influence on bird communities. Many species have become adapted to live in tall grasslands $(>50 \mathrm{~cm})$ and have become highly specialized in this regard, notably the globally threatened Bristled Grassbird Chaetornis striatus, Jerdon's Babbler Chrysomma altirostre, and Slender-billed Babbler and near-threatened Rufous-rumped Grassbird, as well as some Prinia spp., Saxicola spp., Striated Grassbird Megalurus palustris, Yellow-eyed Babbler Chrysomma sinense and Chestnut-capped Babbler Timalia pileata. It is vital to maintain some tall grassland if these species are to survive (Baral, 2001). 
The most noticeable effect brought about by livestock grazing is the drastic decrease of grass height. Species that prefer tall grassland are absent from these areas. Heavily grazed grasslands are suitable for species like pipits, wagtails, and larks. Although overgrazed grasslands provide habitat for many common bird species, many threatened species are absent (Baral, 2001). Grazing livestock and herders often cause significant disturbance to and trampling of ground-nesting birds.

Grasslands that are subject to cutting showed drastically reduced species diversity and abundance. However, the globally threatened Swamp Francolin Francolinus gularis (chiefly a species of tall grassland), and pigeons and doves benefit temporarily from cutting as they have been frequently noted feeding in the clearings close to tall grasslands.

Large areas of burnt open grasslands are ideal for bird species hunting insects in the air and small animals on the ground. These areas offer a means of subsistence for White-throated Kingfisher Halcyon smyrnensis, bee-eaters, rollers, owls, Longtailed Shrike Lanius schach, drongos, Ashy Woodswallow Artamus fuscus, Darkthroated Thrush Turdus ruficollis, stonechats, swallows, and Jungle Myna Acridotheres fuscus. All these species were found to specialize in exploiting this ephemeral resource. The globally threatened Bengal Florican was seen feeding on new grass shoots only two days after a fire (Baral, 2001).

After the grasses have regenerated and the effect of fire is no longer apparent, many grassland species that disappeared temporarily return. Some chats Saxicola spp. and Luscinia spp., drongos and mynas show a marked preference for burnt rather than unburnt grasslands.

Burning may be considered as a strong management tool to maintain biodiversity in lowland grasslands. It should be carried out between October and January, i.e., outside the breeding season of grassland birds (Baral, 2001). Late fires can be extremely damaging to nests and eggs (Inskipp and Inskipp, 1983). Another risk is that burning may be too comprehensive, leaving no shelter for grassland wildlife (BirdLife International, undated).

Many species that live exclusively in dense tall grassland show a marked preference towards unburnt grasslands. Most of these are grassland specialists, such as Jerdon's Bush Chat Saxicola jerdoni, Yellow-bellied Prinia Prinia flaviventris, Striated Grassbird, Rufous-rumped Grassbird, Bristled Grassbird and Chestnutcapped Babbler (Baral, 2001).

The Koshi dam and accompanying embankments extending c. $37 \mathrm{~km}$ on the eastern side and c. $10 \mathrm{~km}$ on the western side of the Koshi river were constructed from 1958-62 by the Indian government to control flooding and provide irrigation water for India. These constructions resulted in frequent monsoon flooding of wet grasslands with the complete inundation of all grassland refugia that are vital for the survival of sedentary grassland specialists. This regular and complete pattern of flooding probably explains the absence of a few grassland birds at Koshi which are fairly common in similar grassland types in Chitwan and Sukila Phanta, notably Rufousrumped Grassbird and Chestnut-capped Babbler (Baral, 2001). 
Dams and irrigation systems elsewhere in the country have altered species composition favouring certain types of grassland assemblages and eliminating others.

Grasslands in the hills and mountains of the subtropical, temperate and subalpine zones are so denuded that the amount of seed and insect food available to birds must be much reduced. Ground-nesting birds are especially likely to be disturbed and nests trampled. In a survey of Wood Snipe Gallinago nemoricola in Langtang National Park, herders were found to deliberately graze their pastures intensively in order to maximize quality and productivity of their livestock. These high levels of stocking were considered to be causing unacceptable disturbance to the breeding Wood Snipe and may result in unsustainable losses of nests to trampling (Khatiwada and Chaudhary, $2008 \mathrm{a}, \mathrm{b}$ ). There have been no other studies on birds in the Himalayas to show the effects of overgrazing of high altitude grasslands. Indeed, in Nepal virtually all these grasslands are very overgrazed and there are no moderately grazed areas for comparison.

Overgrazing of grasslands in the hills and mountains leads to significant soil erosion resulting in streams and rivers becoming turbid, with reduced populations of invertebrates and fish. The water turbidity must also reduce the ability of Brown Dipper Cinclus pallasii and Whitethroated Dipper $C$. cinclus to locate and catch their prey (Tyler and Ormerod, 1993).

\section{Wetlands}

\section{Importance of wetlands for birds}

Wetlands form only 5\% of Nepal's area (DOAD, 1992), but 193 bird species (22\% of the total recorded in the country) depend on them (IUCN, 2004). Of the 35 globally threatened species recorded in Nepal, 15 are wetland birds (43\%), see table 1 . In addition a total of 12 out of 24 near-threatened species $(50 \%)$ inhabit wetlands, see table 2 (BirdLife International, 2010). Many of the wetland birds found in the country are passage migrants and winter visitors (Inskipp and Inskipp, 1991).

Wetlands in the lowlands and lower hills are by far the most important for birds as the waters are richer in nutrients and so support more aquatic plants, invertebrates and fish that are vital food sources. In the mountains wetlands are invariably oligotrophic and lakes are relatively deep compared to those in the lowlands. However, lakes and ponds in the high Himalayas are still valuable staging posts for the relatively small number of transHimalayan migrants, for example Rara Lake and frequently lakes as high as $4570 \mathrm{~m}$ at Gokyo lakes in Sagarmatha National Park.

The Koshi Tappu Wildlife Reserve and the Koshi Barrage area (Sunsari district) contain the most important wetland for migratory water birds in Nepal (Baral and Inskipp, 2005) and one of the most important in Asia (Sah, 1997). The whole area was designated a Ramsar site, a Wetland of International Importance in 1987. As many as six globally threatened wetland and 15 near-threatened wetland bird species have been recorded there (Baral and Inskipp, 2005). The reserve has the largest heronry in Nepal, with 25,730 nests belonging to 12 species reported in 1996 (Choudhary, 1996). This heronry is shifting 
from place to place and now exists on inaccessible islands in the Koshi river, so recent counts have not been possible (VAN Baral pers.obs.). Other Ramsar sites which are of special value to birds are Ghodaghodi Lake Area (Kailali district); Jagdishpur Reservoir (Kapilvastu district), and Beeshazar and associated lakes (Chitwan) in the lowlands, and Rara Lake (Rara National Park) and Gokyo Lake (Sagarmatha National Park) in the high Himalayas (Baral and Inskipp, 2005). The Koshi Tappu and Koshi Barrage area, Ghodaghodi Lake area, and Jagdishpur Reservoir have been identified as Important Bird Areas, and Beeshazar and associated lakes, Rara Lake and Gokyo Lake lie within other Important Bird Areas (Baral and Inskipp, 2005).

\section{Impacts of agriculture on wetlands}

Drainage for agriculture is a continuing threat to wetlands in the lowlands. Waterlogged areas and marshy ground are especially vulnerable to paddy field conversion (Bhandari, 2009; Kafle and Savillo, 2009). Unsustainable harvesting of resources is a major threat to lowland wetlands, notably at Koshi, Jagdishpur and the Ghodaghodi Lake area.and is leading to the degradation of wetland habitats (HMGN/MFSC, 2002; Kafle et al., 2007; 2008; Kafle and Savillo, 2009; Thapa and Dahal, 2009). For example, at Koshi, 16\% of households within the vicinity collect fodder from the reserve (Kafle et al., 2008).

Other widespread threats are diversion and abstraction of water for irrigation of farmland, (HMGN/MFSC, 2002; Baral and Inkipp, 2005), for example at Jagdishpur Reservoir (Ramsar Convention Secretariat, 2004).
Studies in the Likhu Khola revealed that work by farmers on irrigation channels frequently resulted in very high sediment loads in water in tributaries; ploughing also caused increased silt loads and turbidity (Tyler and Ormerod, 1993).

Water pollution from agricultural chemicals has been identified as a serious threat to lowland wetlands (IUCN, 2004; Baral and Inskipp, 2005; Kafle et al., 2007, 2008). Agricultural runoff and seepage of fertilizers and pesticides are also major sources of groundwater pollution in the terai. Other sources of agricultural water pollution include veterinary drugs and wastes, and effluents from veterinary drug and vaccine factories that are released into the environment. In addition, effluent from agricultural processing factories, such as sugar, breweries, leather, slaughter houses and bones, release polluting effluent to the environment (Pant, 2007).

Agricultural pollutants, including pesticides, herbicides and fertilizers can lead to severe environmental pollution that often causes habitat change and loss of biodiversity, including the loss of bird species from wetlands (Pant, 2007), see sections Pesticide Use and Fertilizer Use below.

Overgrazing of shoreline and marshes is another major threat, especially at lowland sites. At Koshi Tappu overgrazing and the movement of livestock along the shoreline contribute to soil erosion and high input of nitrogenous nutrients to the wetland, resulting in increased eutrophication of water and excessive growth of certain aquatic vegetation (IUCN Nepal, 2004). A recent study showed that 12,600 cattle regularly graze the shoreline 
C. Inskipp and H.S. Baral / Our Nature (2010) 8: 270-312

of Ghodaghodi Lake where the composition of aquatic vegetation is gradually changing into terrestrial communities (Kafle et al., 2007).

\section{Impacts of agriculture on wetland birds}

At a national level, as many as 44 wetland species (37\% of the total at risk) have been considered threatened. The large proportion of $64 \%$ of these has been placed in the Critically Endangered or Endangered categories (Baral and Inskipp, 2004).

The Annual Midwinter Waterbird counts have highlighted a sharp drop in waterfowl numbers and species at Koshi Tappu Wildlife Reserve and the Koshi Barrage area (Inskipp and Baral, 2004). In January 2010 a total of 4,284 birds was counted in the whole area $(\mathrm{H}$. S. Baral, pers. obs.), a very low number compared to more than 50,000 birds estimated in February 1981 by observers who only viewed a limited part of the area from land at Koshi Barrage (Mills and Preston, 1981; Porter et al., 1981). In recent years bird populations and species richness have also declined in Ghodaghodi Lake and even more in Beeshazar (Baral, 2009). Although Jagdishpur Reservoir, was considered to have a good bird diversity only a year previously (Baral, 2008), monitoring data since have indicated a rapid decline in populations and species richness there too (Baral, 2009).

Loss of wetlands caused by conversion to agricultural lands and diversion of water for irrigation must have caused significant declines in wetland birds, especially since the 1950 s when the eradication of malaria from the terai sharply encouraged the spread of agriculture.
Further, Nepal's wetland bird populations face widespread degradation of wetland habitats caused by an array of threats including many that arise from agriculture.

Lack of food, especially fish was considered a major factor in the decline in numerous wetland bird species (Baral and Inskipp, 2004). For example the globally threatened Indian Skimmer Rynchops albicollis, near-threatened Black-bellied Tern Sterna acuticauda, as well as Gullbilled Tern Gelochelidon nilotica, Caspian Tern S. caspia and River Tern S. aurantia were all categorized as Critically Endangered nationally, partly because of fish shortages (Baral and Inskipp, 2004). At Koshi, where these species have been mainly recorded, over-fishing by local subsistence villagers is thought to be the cause of the depletion of fish populations (Baral and Inskipp, 2004). However, EUS disease, which has caused major fish kills in the area (see Fertilizer Use section below) and is thought to probably result from water contamination by inorganic fertilizer from agricultural run-off, is likely to be another factor.

Increased water turbidity caused by soil erosion resulting from overgrazing, ploughing and work on irrigation channels by farmers must be making it difficult for fish-eating birds to locate their prey. This could be a major additional reason for food shortages in piscivorous birds, for example in the lowlands at Koshi Tappu and Koshi Barrage. The Common Merganser Mergus merganser, a fish-eating winter visitor to Nepal's rivers, is also likely to be affected.

Impacts of livestock overgrazing of shorelines and marshes have not been 
C. Inskipp and H.S. Baral / Our Nature (2010) 8: 270-312

published but both the disturbance and changes in vegetation height and composition must affect the feeding and nesting of many wetland bird species. However, some grazing along shores outside the birds' breeding season can be beneficial to many water birds. For example, lakes inside Nepal's protected areas may suffer from lack of grazing due to insufficient numbers of herbivores. The result is the spread of grasses and other vegetation, even native plants, covering the entire lake system so making them unsuitable for many wetland birds $(\mathrm{H}$. S. Baral, pers. obs.).

\section{Forests}

\section{Importance of forests to birds}

Over three-quarters of Nepal's breeding bird species $(77 \%)$ and $67 \%$ of wintering species utilize forests or shrubs. These high proportions can be partly attributed to forests and shrubs forming major habitats in the country and also because they comprise a wide range of types growing in tropical, subtropical, temperate, subalpine and alpine zones (Inskipp, 1989). Seven globally threatened species $(20 \%$ of the total in Nepal) including White-bellied Heron Ardea insignis and Rufous-necked Hornbill Aceros nipalensis which are now extirpated in the country, depend on forests, see table 1. Six near-threatened species $(25 \%$ of the total in Nepal), see table 2, also require forest habitats (BirdLife International, 2010).

The large majority of $78 \%$ (21 of the 27) Important Bird Areas in Nepal has been designated partly because of their importance for forest species. Amongst the IBAs the Annapurna Conservation Area, Kanchenjunga Conservation Area and
Makalu Barun National Park have the widest range of forest types from subtropical to alpine and therefore support the largest number of forest bird species (Baral and Inskipp, 2005).

\section{Impacts of agriculture on forests}

Continuing forest clearance is now by far the most important option utilized to make way for new agricultural lands (Bajracharya, 1983).

According to the 2005 FAO Global Forest Resources Assessment, 25.4\% of Nepal was covered by forest in 2005. Nepal lost $24.52 \%$ of its total forest area between 1990 and 2005. The rate of decrease of primary forests was even higher. During 1990-2000 Nepal lost 700 ha of primary forest per year, but this figure rose by 10 times to $7000 \mathrm{ha} /$ year between 2000 and 2005. However, other wooded area (with tree canopy cover 5-10\%), i.e., degraded forest) increased from $1,180,000$ ha to $1,897,000$ ha during the same period. There were significant increases in afforestation between 1990 and 2005: the plantation area increased from 49,000 ha to 53,000 ha. (Forestry Nepal, 2005; Parajuli, 2005). The Ministry of Environmental Science and Technology in Nepal (2006) considered that as much as $28.2 \%$ of Nepal is degraded land and $36 \%$ of this is poorly managed forest.

Demands for fuelwood by local people and tourists and wood for building are other important causes of deforestation, in addition to pressure from agriculture.

In 1978 there was a shift in government policy from 'state-controlled' to 'community-managed' forests. By April 2009, one-third of Nepal's population was participating in the programme, directly 
managing more than one-fourth of Nepal's forest area (Ojha et al., 2009). The programme promotes afforestation in Nepaland has also brought other environmental improvements, including more sustainable use and collection of forest products, although the poorest and most marginalised members of communities have been found to receive the fewest benefits (Adhikari, 2005).

Forests are vitally important resources to provide fodder for the livestock of rural households, particularly in the hills and mountains (Shrestha, 1999). Famers keep animals for manure, draught power and for extra income. Huge amounts of vegetation are consumed by livestock, both by roaming in the forests or where stall fed in villages (Shrestha, 1999). Demand for fodder is probably the greatest pressure on Nepal forests (Regmi, 1994; Wallace, 1988). According to some estimates there are nine times more grazing animals than the land can viably support (HMGN/MFSC. 2002). Overgrazing by livestock, along with trampling contributes greatly to forest degradation (Wallace, 1988), leading to a severely reduced understory and a thinned, drier forest, with a reduced number of mature trees. Overgrazing by livestock is also reducing ringal bamboo in many areas e.g., in Dhorpatan Hunting Reserve, and herders and their dogs are causing disturbance (Subedi, 2008).

Overgrazing compacts the soil, inhibits water penetration and aeration, and more importantly prevents seeds from germinating. The seeds that do manage to grow despite this are then destroyed by grazing (Banerjee, 1995). Ultimately forests are prevented from regenerating. A study on
Sal Shorea robusta and Saj Terminalia alata forest in the buffer zone of Bardia National Park found that overgrazing had severely reduced seedling regeneration of both tree species, putting the sustainability of the forest at risk (Acharya et al., 2009). Overharvesting for fodder prevents trees from flowering, producing seed and regenerating (Wallace, 1988). Overlopping, particularly during the trees' dormant season kills trees after a while (Banerjee, 1995).

Forests provide farmers with leaf litter which is used for livestock bedding during winter, and is an important source of compost used for manure during the following summer. However, in some forests, the floor is swept clean of the litter to such an extent that regeneration of seedlings is prevented, as noted in Phortse, Dudh Kosi valley, Sagarmatha National Park (Inskipp and Inskipp, 1994). About four tons of organic manure is applied per hectare of agricultural land. Wood from local forests is used to make agricultural implements, especially by subsistence farmers (Kanel and Shrestha, 2001).

During the dry season (May -June) some forests are deliberately burned to stimulate early growth of grass for livestock to graze (Bajracharya, 1983). This practice is a particularly common phenomenon in Siwalik Sal forests (Sharma, 1996). It favours the spread of fire-resistant species, such as pines. Pines are often naturally succeeded by broadleaved trees, but frequent fires prevent this.

As forest areas have reduced, the supply of forest fodder available to feed livestock has been declining over the years, resulting in increasing pressure on 
remaining forests (Regmi, 1994). The everrising livestock populations are exacerbating the over-exploitation of forests (Shrestha, 1999). Ongoing environmental degradation has resulted and is being made worse by the fragile nature of the mountain environment (Takahatake, 2001). In some areas, especially in the more remote hills, land degradation has been worsened by slash and burn agriculture (Shrestha, 1999).

A direct consequence of high population growth has been rapid expansion of agriculture in environmentally sensitive and marginalized steep slopes at the cost of forest (Bhurtel and Ali, 2009; Shrestha, 1994). Terracing and overgrazing on oversteep slopes has lead to the acceleration of the already high natural soil erosion processes. Severe soil losses and landslides are widespread every monsoon season. Bishop (1990) reported rampant erosion from fields carved from hillsides with an angle of slope of more than $40^{\circ}$ at elevations as high as $3700 \mathrm{~m}$ as long ago as the 1960s. A 2009 study to assess runoff and soil erosion in the Middle Mountains in Dhading district reported that soil loss from agricultural land (1.3 $\left.\mathrm{Mg} \mathrm{ha}^{-1} \mathrm{yr}^{-1}\right)$ was more than four times higher than that from forested areas $\left(0.3 \mathrm{Mg} \mathrm{ha}^{-1} \mathrm{yr}^{-1} ; p<0.05\right)$ (Tiwari et al., 2009).

\section{Impacts of agriculture on forest birds}

A total of 78 nationally threatened birds (59\% of species at risk) depend on forests. This high proportion is the result of serious loss and degradation of this extensive habitat type in Nepal, and agriculture has been significantly to blame (Baral and Inskipp, 2004).
The loss or reduction of the forest understorey must drastically affect bird species composition. Many species, including pheasants, babblers, warblers, chats and thrushes inhabit this part of the ecosystem. These include the globally threatened Cheer Pheasant Catreus wallichii, and near-threatened Satyr Tragopan Tragopan satyra and Rufousthroated Wren-Babbler Spelaeornis caudatus. Removal of foliage must result in forests becoming less suitable for the numerous species which require dense or moist forests. Some birds feed on branches, trunks and boulders that are moss-covered or on epiphytes that can only grow in moist forests (Inskipp, 1989), such as Rufousthroated Wren-Babbler. Some species, including the near-threatened Great Hornbill Buceros bicornis and other hornbills, and certain large woodpeckers such as the globally threatened Great Slaty Woodpecker Mulleripicus pulverulentus, and nationally threatened Spot-bellied Eagle Owl Bubo nipalensis depend on mature trees for suitable nest sites (Inskipp and Inskipp, 1991; Baral and Inskipp, 2004).

Some species occur mainly in pure bamboo stands, for example the nationally threatened Golden-breasted Fulvetta Alcippe chrysotis and Fulvous Parrotbill Paradoxornis fulvifrons. Other species favour forests with a bamboo understorey, such as Satyr Tragopan. All these species must have been affected to some degree by bamboo losses (Inskipp, 1989).

The open forests of pines lacking undergrowth that result from frequent burning of the forest floor only support a low variety of bird species compared to the original forest (Inskipp, 1989). 
Species which prefer open forests, such as some flycatchers, must have benefited from forest thinning and burning. Presumably species which prefer scrub, such as Himalayan Bulbul Pycnonotus leucogenys, Grey Bushchat Saxicola ferrea and Striated Prinia Prinia criniger must have also increased as a result of the spread of secondary forest and shrubberies. However, most species in this category are common and widespread in Nepal, whilst many forest species are declining (Inskipp, 1989).

Slopes become so degraded by erosion that they are reduced to rough grass and rocky habitats, which are only able to support a limited number of bird species.

The replacement of forests by agricultural lands will certainly have reduced forest bird populations, while birds of open country are likely to have increased. Overall forest depletion can have benefited relatively few species and the populations of most Nepalese forest species are likely to have decreased, but these changes in bird populations have not been monitored in Nepal to date. Inskipp (1989) estimated that only $16 \%$ of Nepal's bird species had adapted to habitats heavily modified or created by people, such as groves, gardens, scrub and trees and bushes at the edges of cultivation. Nearly all of these birds are widespread and common, and presumably they once bred in forest edges, gaps and clearings. However no up-to-date studies have been made in this subject area.

\section{Impacts of other habitat loss on birds}

Farmers are now forced to cultivate all available land, even farming small patches resulting in the loss of field corners and strips of land at field edges. These marginal pieces of land which form valuable habitats for the cranes are increasingly being cultivated; and river banks are being farmed for melons in Lumbini, for example (Paudel, 2009 a, b).

\section{Pesticide use}

The first chemical pesticide introduced into Nepal was DDT, during the 1950s for malaria eradication, and was followed by other organochlorines, organophosphates, carbamates, and then synthetic pyrethroids.

Over the years, a steadily increasing trend in pesticide use in Nepal has been documented, with the exception of a few very recent years (2004-2006) when a decrease was recorded (Pesticides Registration and Management Section, 2006; Plant Protection Directorate, 2003; 2007). Gupta (2004) reported that the per capita consumption of pesticides in Nepal $(0.142 \mathrm{~kg} / \mathrm{ha})$ was still very low compared to other countries, such as India $(0.5 \mathrm{~kg} / \mathrm{ha})$ and Japan $(12 \mathrm{~kg} / \mathrm{ha})$. According to Shah (2006), writing on behalf of the Center for Public Health and Environmental Development, Kathmandu, a total of 176 MT active ingredients of pesticides was imported and 184 MT active ingredients consumed during 2003. However, Atreya (2007a) pointed out there were no comprehensive records that indicated the volumes of pesticides used in agriculture and therefore released to the environment. The use of pesticides in lowland Nepal is significantly higher compared to the mid hills and high mountains.

Further market-oriented production (i.e., growing cash crops), as well as agricultural intensification of other crops, 
have been leading farm workers to increase pesticide use at a rapid rate to boost yields and so meet market demand, while earning more income (Brown and Shrestha, 2000).

There is widespread documentation of farmers' lack of awareness of pesticides, including impacts on the environment and the ongoing need for farmers' education and development of safety culture in pesticide use e.g., Dahal (1995), Ghimire and Khatiwada (2001), Shrestha and Neupane (2002), Palikhe (2005) and Nepal Forum for Justice (2006).

During an investigation of threats to Sarus Crane at Lumbini, Paudel (2009 a, b) carried out a survey of local markets and found that a wide range of pesticides was available and a disturbingly large range of insecticides was being used in the area. Out of 71 pesticides available locally, 23 were moderately hazardous and seven were highly hazardous according to WHO standards (Paudel, 2009 b). High illiteracy levels often led to the printed recommendations for safe use being ignored. Illiterate farmers were reliant on the dealers for advice on how to use the pesticides, so there was a high risk that they were being used inappropriately. Further, a lot of pesticides were being sold outside of the regulated trade in Lumbini (Paudel, 2009).

Since April 2001, in Nepal persistent chemical pesticides have been banned for use in agriculture and public health. The use of hazardous pesticides, including Persistent Organic Pollutants (POPs) (organic chemicals that are resistant to environmental degradation), has also been phased out. However, Palikhe (2005) reported that, as the country has an open and porous border with India, there is a considerable, but unknown quantity of trade between farmers close to the border. This is confirmed by Paudel (2009b) who found that some pesticides used by farmers in Lumbini originated from across the border in India. Palikhe (2005) believed that the illegal import of pesticides was of serious concern in Nepal and that it needed to be addressed. The Nepal Forum for Justice (2006) shared the same view and reported that, in spite of the Pesticides Acts and Regulations, different kinds of pesticides were being used haphazardly in the country. A recent survey made by the Entomology Division, Khumaltar, indicated that farmers were still using pesticides identified as POPs, such as DDT (Nepal Forum for Justice, 2006).

According to Nepalese law, it is mandatory for a person or firm to acquire a certificate of registration before the import, export, sale or purchase of pesticides. However, the Nepal Forum for Justice (2006) pointed out that in practice in many parts of the country, the sale of pesticides still took place openly without following these guidelines.

Pesticide problems that have been identified to date in Nepal include pollution generated during improper handling, storage and transport, and also accidents and environmental contamination due to unsound disposal methods. Pest resistance to chemical pesticides is considered of major and increasing concern as well. In common with many other developing countries, analysis of pesticide residue in crops, food products, soil and water and the environmental effects of pesticides have not been systematically studied and monitored in Nepal (Palikhe, 2005). Ghimire and 
Khatiwada (2001) pointed out that there appeared to be two distinct areas of pesticide problems: misuse in general and overuse in specific areas.

A recent study by Koirala et al. (2007) reviewed the occurrence of pesticides in foods in Nepal during 19952004. Among a total of 1,034 samples of different food commodities analysed, $12 \%$ of samples were detected with residues of pesticides including malathion (3.9\%), BHC (3.1\%), methyl parathion (2.8\%), DDT $(1.8 \%)$ and parathion $(0.3 \%)$. Commoditywise detection of pesticide residues showed the highest level of contamination in root vegetables $(11.9 \%)$, followed by leaf vegetables $(10.9 \%)$.

Sharma (1994) reported that the application of pesticides on commercial vegetables was $1450 \mathrm{~g} / \mathrm{ha}$, which is exceptionally high in the Nepalese context. Atreya (2005) and Shrestha and Neupane (2002) also reported significantly high use of pesticides in cash crops in the central mid-hills. Shrestha and Neupane (2002) found that while rice, maize, wheat and mustard were treated one to three times per crop cycle, the cash crops potato, tomato, cabbage, bitter gourd and cucumber were treated two to 15 times. As farmers do not like to risk pest damage in their cash crops they use pesticides lavishly. High use of pesticides can also be attributed to their cheapness and their very low share in the total cost of crop production.

In order to control disease and pests that are a major constraint to better productivity of potatoes, farmers indiscriminately apply various chemicals, e.g., Malathion, BHC, Methyl parathion, DDT, Parathion (Koirala et al., 2007), posing threats to the environment and human health. Since the 1990s the International Potato Center has been working to help Nepalese potato communities tackle these diseases by formulating an Integrated Disease Management Strategy (2006).

For 50 years warehouses across the country, including at Amlekhgunj, Bara district and Khumaltar in Kathmandu have stored obsolete pesticides imported during the 1950s and 1960s for farming and malaria eradication. Today, some 74.5 MT of obsolete pesticides remain stored in 24 locations, the majority of which belong to POPs, including dioxins, DDT and PCBs, and pose a serious hazard to environment, wildlife and public health through leakage (Tumbahangphey, 2006; Shah and Devkota, 2009).

Ordinary citizens are worried that the government's method of waste disposal will have a lasting impact on the whole environment and on human health. The largest store of obsolete pesticides is at a warehouse in Amlekhgunj, which contains 50.90 MT and 60 litres of HDPC (MoEST, 2005). A recent study by Shah and Devkota (2009) revealed that pesticides residues had contaminated soil in the grounds of a nearby school and were having adverse health effects on local school children.

Concern has been expressed that climate change will increase pest populations, including weeds, invasive species, insects and insect-borne diseases, which will likely lead to further large increases in pesticide use (Palikhe, 2007; Koirala et al., 2009). A wide range of adaptive actions have been recommended to lessen or overcome the adverse effects of 
climate change on agriculture and to discourage the use of pesticides. These include adopting an Integrated Pest Management (IPM) approach, the introduction of later-maturing crop varieties or species, switching cropping sequences, sowing earlier and adjusting the timing of other field operations, organic farming, and the use of organic manure, as well as more research and development to support pesticide reduction in agriculture (Palikhe, 2007; Koirala et al., 2009).

Koirala et al. (2009) pointed out there was an urgent need to establish a national pesticide residue monitoring programme and also periodic assessments of the level of pesticides use. In addition, they advocated the Introduction of Good Agricultural Practice in the country, which should help to reduce the pesticide risk, and they also recommended the effective implementation of existing legislation and regulations: the Pesticide Act 1991 and Pesticide Regulations 1993.

\section{Alternatives to pesticides}

Nepal's National Agricultural Perspective Plan has recently emphasized the IPM approach to try and reduce pesticide use. However, very few individuals are IPMtrained (Atreya, 2007b) and adoption of safety precautions and pesticide hygiene are still minimal (Atreya, 2007a).

Ghimire (2008) argued the case for farming with no or low use of agrochemicals and believed this was necessary to achieve sustainable development of Nepalese agribusinesses. In addition, he believed this strategy would be beneficial to Nepal by helping to create a low carbon economy in the country.
The potential for organic agriculture in Nepal was reviewed by Bhatta et al. (2009) who carried out research in the Kathmandu valley. Organic production was considered small and organic farmers were found to be reliant on consumers' willingness to pay more to compensate for lower crop yields. The Nepalese organic sector was growing in a sluggish manner; the key impetus was coming from NGOs and there was virtually no government support (Bhatta et al., 2009).

Since 2004 the Bird Education Society has been carrying out a successful conservation awareness programme in the buffer zone areas around Chitwan National Park. The programme has taught farmers about the environment, introduced them to organic farming, made them aware of the dangers of overuse of pesticides and suggested alternative methods of control. The farmers were introduced to the Effective Microorganism (EM) technology, which relies on the use of natural microorganisms in the soil to fix the essential nitrogen for plant growth, as it is important that the soil should be chemicalfree to ensure the survival of these microorganisms. Farmers learned how to use EM technology to produce fertilizers, recycle waste products and control crop pests. They learned the benefits of EM technology in improving soil composition and structure through an increase in humus content and the capacity to sustain highquality food production. The adVantages of IPM were also covered in the programme. Field trips to an organic cooperative convinced the farmers that they could successfully produce organic food and sell it at a premium price to a growing organic 
market (Benstead et al., 2005; Chaudhary, 2005).

In 2007 and 2008, Himalayan Nature carried out a successful conservation awareness programme with farmers in Lumbini in Nepal's central lowlands. The programme aimed to create a positive attitude amongst farmers towards birds on their land, to encourage the continuation of traditional farming methods, to reduce use of chemicals, especially their haphazard and excessive use, and to encourage participatory monitoring of birds by farmers (Singh, 2007).

\section{Impacts of pesticides on birds and the environment}

While there have been several studies on the impacts of pesticides on human health (Atreya, 2005; 2007a; b; 2008), there are very few published results of the effects of pesticide contamination on the environment in Nepal. Organochlorine pesticides in the range of 34-100 parts per billion were detected in samples of fish and plankton in three lakes: Begnas, Phewa and Rupa in the Pokhara valley, west Nepal (Palikhe, 1999). High pesticide use was noted at most of the places that Sarus Cranes were recorded during a survey of the Lumbini area (Paudel, 2009).

Groundwaters, surface waters such as ponds and streams, and the air in the vicinity of the pesticides stores are all at risk. Evidence elsewhere in the world has shown that chemical pesticide contamination can travel widely through the environment (National Toxics Network, 2007). Pesticide contaminants have even been found in the Arctic where animals can be subject to very high levels of pollution.
Air and water carry contaminants from further south. Many aquatic animals including birds accumulate these contaminants in their bodies at much higher levels than in the surrounding water (National Toxics Network, 2007).

Many chemical pesticides, including organochlorines like DDT, remain in the environment for a very long time, do not readily break down (i.e., they are very 'persistent') and also build up in the environment, including in the bodies of humans and birds (i.e., they are bioaccumulative). Once released into the environment it is extremely difficult, if not impossible, to recover them (National Toxics Network, 2007).

As well as being direct poisons, some pesticides, e.g., DDT, also mimic hormones and disrupt biological processes in wildlife and humans. In some cases hormonedisrupting chemicals are also very persistent and build up in the environment and body tissue. Their effects can include direct poisoning and reproductive damage (Lyons, 1999; Riley et al., 1999).

The diet of certain birds, such as insect eaters and top predators like birds of prey, means they are particularly at risk from pesticide pollution as they store up and concentrate contaminants that they have ingested with their prey in their body fats (BirdLife International et al., 1997).

In the UK and the rest of Europe, pesticide use has been shown to cause widespread declines of numerous bird species, many of which were previously common, including birds of prey and finches (BirdLife International et al., 1997; Tucker and Heath, 1994). For example, in the 1960s widespread use of the pesticide 
DDT led to the thinning of eggshells resulting in egg breakages and breeding failure, especially of birds of prey such as Peregrine Falcon Falco peregrinus and Eurasian Sparrowhawk Accipiter nisus. DDE, a breakdown product of DDT, is persistent and builds up in fat, so birds at the top of the food chain-including birds of prey, like Peregrine were particularly affected, several being brought close to extinction (Santa Cruz Predatory Bird Research Group, 2007; Canadian Peregrine Foundation, 2009; RSPB, 2009).

In addition to direct poisoning and endocrine disruption, pesticides can have indirect effects on birds. These indirect effects are very difficult to demonstrate, but there is large body of evidence in the U.K. suggesting these effects are key problems (Central Science Laboratory et al., 2005). There are three possible routes by which these indirect effects can arise. Insecticides may deplete or eliminate arthropod food supplies, which are exploited by adult birds and their dependent young during the breeding season and, in so doing, reduce breeding productivity. Herbicides may reduce the abundance of, or eliminate noncrop plants that are hosts for arthropods taken as food by farmland birds during the breeding season and therefore reduce breeding activity. Herbicides may also deplete or eliminate weed species, which provide either green matter or seeds for herbivorous and seed-eating species respectively, thereby reducing survival of those birds that rely on those food supplies (Central Science Laboratory et al., 2005).

Although pesticides may be having serious impacts on Nepal birds and there have been indications of bird poisoning by pesticides, no Nepal studies have been published to date.

In an overview of the state of Nepal's birds, Baral and Inskipp (2004) list pesticide poisoning as a possible threat to 20 species, mainly birds of prey and large wading birds such as storks, including six globally threatened species: Lesser Adjutant, Pallas's Fish Eagle Haliaeetus leucoryphus, Indian Spotted Eagle, Greater Spotted Eagle A. clanga, Imperial Eagle A. heliaca, and Sarus Crane (BirdLife International, 2010). Nationally threatened raptors that may well have been impacted by pesticides include Brahminy Kite Haliastur indus. This bird of prey was formerly common in the lowlands over rice fields and marshes (Rand and Fleming, 1957) but declined so sharply that it was considered Critically Endangered nationally by Baral and Inskipp (2004).

During preparations for the midwinter waterbird count in January 2010, several water birds were recorded dead, possibly due to pesticides and poisoning. These included as many as seven Lesser Adjutants (four in Urlabari and three in Chitwan (Badri Chaudhary and Bishnu Mahato pers comm. to VAN Baral, February 2010). In addition, at Chitwan, five Black-crowned Night Herons Nycticorax nycticorax, and more than 10 Indian Pond Herons were found dead on 26 December 2009 in Chitwan (Bishnu Mahato pers comm. to $\mathrm{H}$. S. Baral, February 2010). Some common open country species such as Black Drongo Dicrurus macrocercus may have declined in recent years as a result of direct poisoning and partially by the diminution of open spaces in the country. Preliminary observations suggest that Indian Cuckoo Cuculus micropterus, which is a brood 
parasite for the drongo has also declined (VAN Baral pers. obs.). Further studies are needed to show the rate of decline and other factors that are causing decline of these species.

\section{Fertilizer use}

Nepal imports all of its chemical fertilizer (Ministry of Agriculture Fertilizer Unit, 2002). Official fertilizer imports have declined every year since 1997 when the fertilizer trade was deregulated by the government. However, when informal imports (that is they were unrecorded imports from across the open border with India) are included, total fertilizer imports can be seen to have increased annually. Thapa (2006) reported that the majority of Nepal's fertilizer imports were informal. Informal imports comprised $65.8 \%$ of total imports in 2000/01 and $71.6 \%$ in 2005/06. Trend analysis and the opinion of traders show that fertilizer uses have increased by about $11.5 \mathrm{~kg}$ per ha every year. When both official and informal imports are taken into account, the Agricultural Sector Performance Review found that the use of fertilizer by household was $58 \mathrm{~kg}$ (nutrient) per hectare in 2000/01. This figure is close to the Agricultural Perspective Plan target level for the year (Thapa, 2006). A National Fertilizer Policy was approved by the Nepalese government in 2002. Fertilizer application rates are much higher for vegetables $(341 \mathrm{~kg} / \mathrm{ha})$ and potatoes (316 $\mathrm{kg} / \mathrm{ha})$ than for paddy $(131 \mathrm{~kg} / \mathrm{ha})$ and wheat $(159 \mathrm{~kg} / \mathrm{ha})$. [N.B. Figures are for fertilized area, not total cropped area] (Thapa, 2006).

\section{Impacts of fertilizer use on birds and the environment}

The over-use of agricultural fertilizers is having a major negative impact on the environment, especially in the lowlands and lower hills.

Widespread contamination of agricultural run-off by nitrogen and phosphate nutrients and eutrophication (i.e., enrichment) of lowland wetlands has resulted (IUCN, 2004; Kafle et al., 2007, 2008). This contamination sets off a chain of events which is harmful to freshwater life, including birds. The growth of algae and other aquatic plants is promoted in streams and ditches draining fields and in nearby ponds and lakes. After this aquatic vegetation dies, it is broken down by bacteria, using up vital oxygen in the water in the process. Declining oxygen levels in the water eventually lead to deaths of aquatic invertebrates and fish that form essential food supplies for freshwater birds.

In addition, high nitrogen and phosphate nutrients can cause the extensive proliferation of macrophyte growth over the water surface. This results in a shift in the balance of bird species as it changes areas suitable for feeding for different species. Birds such as jacanas that feed using floating vegetation are favoured at the expense of many migratory waterfowl that require open water areas for feeding (IUCN Nepal, 2004). There may also be a decline in food plants for herbivorous and omnivorous waterfowl (MacDonald, 2006).

For example, Nakhrodi Lake in the Ghodaghodi Lake complex is being severely affected. Extensive growth of macrophytes has developed in the lake. After dying back, these plants have contributed to the organic material on the lake bottom, raising it and accelerating seral succession towards dry 


\section{Inskipp and H.S. Baral / Our Nature (2010) 8: 270-312}

land. In Nakhrodi, the succession is rapid as the waters are shallow. The lake is now changing into marshland where Salix species and the alien Ipomoea fistulosa are prominent. Changes in bird populations have been especially marked, with egrets, storks and jacanas replacing waterfowl, for instance (IUCN, Nepal, 2004).

Other Ramsar sites where eutrophication from agricultural run-off is a problem are Beeshazar, Jagdishpur and Koshi (Kafle et al., 2007; 2008; Baral, 2008).

Fish-eating birds that chase their prey may be negatively affected by eutrophication as water transparency tends to be reduced. Nutrient enrichment may also alter the size class of fish prey, reducing the abundance of suitable small individuals (MacDonald, 2006).

Eutrophic conditions also radically change the bottom-dwelling invertebrate fauna, leading to a loss of some species, such as mollusks. Diving birds that feeds on these invertebrates suffer from reduced food supply (MacDonald, 2006).

Use of agricultural chemicals on cultivated land adjacent to the Koshi Tappu area is prevalent. Epizootic Ulcerative Syndrome (EUS) has been reported in the area since 1983, where it has caused high mortality of native fish resources. EUS is a disease caused by the fungus Aphanomyces invadans in the internal tissue of fish. It is suspected that the source of contamination of EUS is the excessive use of inorganic fertilizers in the adjacent farmlands and their mixing in the lake system. In Koshi Tappu many of the wetlands have changed from mesotrophic to eutrophic due to the accumulation of nutrients from both natural and human activities (the latter including from agriculture, as well as domestic sewage (IUCN 2004; Kafle et al., 2008).

Increased nitrogen input which is needed to support High Yielding Varieties reduces the diversity of plants and associated invertebrates which are important food sources for birds utilizing agricultural lands. Herbicides have similar effects and also reduce cover for nesting and foraging birds. Excessive use of nitrogen also enhances plant pests, triggering high pesticide use (Van der Weijen, 2010).

\section{Recommendations}

Government measures to promote organic agriculture. Bhatta et al. (2009) considered that government commitment, including the initiation of organic technology research, providing market incentives, and institutionalization of the Nepalese organic movement were imperative to further enhance the organic sector in Nepal.

Government measures to promote and expand implementation of the System of Rice Intensification (SRI).

Government farming subsidies Provision of subsidies by government to maintain traditional farming crops such as millet and barley, to keep land fallow for a period and to leave some field margins and corners uncultivated.

\section{Implementation of further Effective Microorganism (EM) awareness programmes for farmers These programmes would be especially useful in Nepal's protected areas and in their buffer zones.}


Field surveys There is an urgent need in Nepal to significantly expand the monitoring of bird populations and distribution in agricultural lands to determine the impacts of current agricultural practices. Bird species diversity and bird populations in traditionally managed farms need to be determined at a range of altitudes from the terai up to the middle hills. These data from traditional farms can be compared with data on bird species diversity and populations gathered from farms growing cash crops and also those with ricevegetable cropping systems at similar altitudes. In addition, bird species richness and species' status along an east-west gradient in Nepal and during different seasons should be investigated.

Provision of nest boxes Where there is adequate protection for nesting birds, providing nest boxes in farmland for owls, such as Spotted Owlet, Jungle Owlet Glaucidium radiatum will help to control mice and rat pests. Nest boxes in agroforestry areas and orchards for tits Parus spp. will help to control insect pests. Outreach Awareness-raising, education and support for farmers to apply best practice as carried out in farmlands of Lumbini by Himalayan Nature (Singh,2007) and in the buffer zone around Chitwan National Park by the Bird Education Society (Benstead et al., 2005; Chaudhary, 2005).

Van der Wejden et al. (2010) made the following additional recommendations to support farmland birds across the world, all of which would be valuable if implemented in Nepal:
Protection Introduce legal protection of bird-rich farmlands and improve protection of threatened species, ensuring enforcement.

Best Practice Identify and further develop best practice for sustainable bird-friendly farming.

Innovation Develop sustainable farming systems that are highly productive in terms of food as well as ecosystem services, and contain important microhabitats and niches for birds. Explore the actual and potential benefits of birds to farming too.

Ecosystem services Assess and reward farmers supporting services such as soil conservation, water retention, carbon storage and biodiversity, including birdlife.

Partnerships Develop cooperation between all stakeholders including conservationists, farmers, retailers, consumers and government authorities.

\section{Acknowledgements}

The authors are very grateful to D. Buckingham for his valuable comments on the draft of this paper and to T. Inskipp for proof-reading the document and for his useful advice.

\section{References}

Acharya, A.K. and N. Kafle 2009. Land degradation issues in Nepal and its management through agroforestry. J. Agri. Environ. 10: 115-123.

Acharya, G.R., B. Bhatta and A.R. Gyawali 2009. Depredation and deteriorating condition of Shorea robusta and Terminalia alata in Bardia National Park: an imperative to 


\section{Inskipp and H.S. Baral / Our Nature (2010) 8: 270-312}

address park biodiversity sustainably. Banko Janakari 19(1): 37-40.

Acharya, R., R. Cuthbert, H.S. Baral and K.B. Shah 2009. Rapid population declines of Himalayan Griffon Gyps himalayensis in Upper Mustang, Nepal. Bird Cons. Intern. 19: 91-107.

Adhikari, B. 2005. Poverty, property rights and collective action: understand ing the distributive aspects of common property resource management. Environment and Development Economics 10(1): 7-31.

Amgain, L.P. and J. Timsina 2004. Crop and cropping systems research in the central terai, Nepal. Proceedings of the $4^{\text {th }}$ International Crop Science Congress, Brisbane, Australia. http://www.cropscience.org.au/icsc2004/poste r/2/3/1940_amgainlp.htm Accessed 17 February 2010.

Anon 2000a. Private extens ion workers to help farmers grow cash crops in Nepal. Asian Development Bank News Release No. 119/00, 9 November 2000.

http://www.adb.org/printerfriendly.asp?fn $=\% 2$ FDocuments $\% 2$ FNews $\% 2$ F2000\%2Fnr2000119.asp Accessed 16 December 2008.

Anon 2000b. Cash Crop Development Project. The WorldBank.

http://web.worldbank.org/external/projects/ma in?pagePK=64283627\&piPK=73230\& theS ite $\mathrm{PK}=40941 \&$ menuPK=228424\&Projectid $=\mathrm{P} 0$ 10182 Accessed 16 December 2008.

Atreya, K. 2005. Health costs of pesticide use in a vegetable growing area, central mid-hills, Nepal. Himalayan Journal of Sciences 3(5): 81-84. http://www.nepjol.info/index.php/HJS/article/ viewArticle/466 Accessed 2 January 2009

Atreya, K. 2007a. Farmers' willingness to pay for community integrated pest management training in Nepal. Agriculture and Human Values 24: 399-409.

http://www.springerlink.com/content/138368 m516r65814/ Accessed 2 January 2009.

Atreya, K. 2007b. Pesticide use knowledge and practices: a gender differences in Nepal. Environmental Research 104(2): 305-311.
http://www.sciencedirect.com/science?_ob=A rticleURL\&_udi=B6WDS-4N2D63R-

$2 \&$ _user $=10 \&$ \&doc $=1 \&$ fmt $=$ \&_orig $=$ search \&_sort $=\mathrm{d} \&$ view $=c \&$ \&acct $=\mathrm{C} 000050221 \&$ eve rsion $=1 \&$ _urlVersion $=0 \&$ \&userid $=10 \& \mathrm{md} \overline{5}=8$ 249f79a6ad391ae38f283a1daa12c8f Accessed 2 January 2009.

Atreya, K. 2008. Health costs from short-term exposure to pesticides in Nepal. Social Science \& Medicine 67: 511-519.

http://www.sciencedirect.com/science?_ob=A rticleURL\&_udi=B6VBF-4SMGCCF-

$1 \&$ _user $=10 \& \_$rdoc $=1 \& \_\mathrm{fmt}=$ \&_orig $=$ search \&_sort $=$ d \& view $=c \&$ cacct $=\mathrm{C} 000050221 \&$ _ve rsion $=1 \&$ _urlVersion $=0 \&$ \&userid $=10 \& \mathrm{md} 5=\mathrm{f}$ d7e92474f3c15736052ec796cc573d6 Accessed 2 January 2009.

Bajracharya, D. 1983. Deforestation in the fuel/food context: a historical and political perspective from Nepal. Mountain Research and Development 3(3): 227-240.

Banarjee, A.K. 1995. Rehabilitation of degraded forests in Asia. Report number WTP270. World Bank. http://wwwwds. worldbank.org/servlet/main?menuPK=64 187510\&page $\mathrm{PK}=64193027 \&$ piPK $=6418793$ $7 \&$ theS itePK=523679\&entityID $=000009265$ 3970311122942 Accessed 16 January 2010.

Baral, H.S. 2001. Community structure and habitat associations of lowland grassland birds in Nepal. Universiteit Van Amsterdam and Cardiff University. (Ph.D. thesis)

Baral, H.S. 1997. Sukla Phanta: a grassland of international importance. Danphe 6(3): 6-8.

Baral, H.S. 2000. Notes on distribution of some grassland birds in Nepal with reference to Sukla Phanta. Danphe 9(3): 6-7.

Baral, H.S. 2002. Invasive weed threatens protected area. Danphe 11(3): 10-11.

Baral, H.S. 2008. Birds of Jagdishpur Reservoir. Forktail 24: 115-119.

Baral, H.S. 2008. Welcome to Vulture Restaurant. BirdLife Asia Bull. 7(3): 4-5.

Baral, H.S. 2009. Updated status of Nepal's wetland birds. Banko Janakari Wetlands Special Issue pp.30-35. 


\section{Inskipp and H.S. Baral / Our Nature (2010) 8: 270-312}

http://www.nepjol.info/index.php/BANKO/iss ue/view/171 Accessed 31 January 2010.

Baral, H.S. and C. Inskipp 2004. The state of Nepal's birds 2004. Department of National Parks and Wild life Conservation, Bird Conservation Nepal and IUCN Nepal, Kathmandu.

Baral, H.S.and C. Inskipp 2005. Important Bird Areas in Nepal: key sites for conservation. Bird Conservation Nepal and Bird life International, Kathmandu and Cambridge.

Baral, H.S.and C. Inskipp 2009. The birds of Sukla Phanta Wildlife Reserve, Nepal. Our Nature 7:56-81.

http://www.nepjol.info/index.php/ON Accessed 30 January 2010.

Baral, H.S., S. Basnet, B. Chaudhary, H. Chaudhary, T. Giri and S. GC 2007. A new subspecies of Rufous-vented Prinia Prinia burnesii (Aves: Cisticolidae) from Nepal. Danphe 16(4): 110. http://www.birdlifenepal.org/downloads/danfe _december\%2007.pdf Accessed 1 June 2010.

Baral, H.S., S. Basnet, B. Chaudhary, H. Chaudhary, T. Giri and S. GC 2008. A substitute name for Prinia burnesii nipalensis. Danphe 17(1): 1. http://www.birdlifenepal.org/downloads/danfe _mar_08.pdf Accessed 1 June 2010.

Baral, N., R. Gautam and B. Tamang 2005. Population status and breeding ecology of White-rumped Vulture Gyps bengalensis in Rampur valley, Nepal. Forktail 21: 87-91.

Basnet, B.M. Singh 2008. Environment friendly technologies for increasing rice productivity. J. Agri. Environ. 9: 34-40

Bell, D.J. and W.L.R. Oliver 1992. Northern Indian tall grasslands: management and species conservation with special reference to fire. In Tropical ecosystems: ecology and management. Wiley Eastern Ltd, New Delhi, India. pp. 109-123.

Benstead, P., D. Buckingham and M. Crosby 2005 Bird conservation awareness camp for local farmers in $\mathrm{OBC}$ in action, Conservation Fund. BirdingASIA 4: 9.

Bhandari, B.B. 2009. Wise use of wetlands in Nepal. Banko Janakari Wetlands Special Issue. pp.
10-17.

http://www.nepjol.info/index.php/BANKO/iss ue/view/171 Accessed 31 January 2010.

Bhatta, G.D., W. Doppler and B.K. KC 2009.

Potentials of organic agriculture in Nepal. $J$. Agri. Environ. 10: 1-11.

http://www.nepjol.info/index.php/AEJ/artic le/ viewFile/2124/1956 Accessed 2 June 2010.

Bhurtel, J. and S.H. Ali 2009. The green roots of red rebellion: Environmental degradation and the rise of the Maoist movement in Nepal. In The Maoist insurgency in Nepal: Dynamics and growth in the twenty-first century (Eds. M. Lawoti and A. Pahari). Routledge, New York: USA. http://www.uvm.edu/ shali/Maoist.pdf Accessed 18 January 2010.

Bird Conservation Nepal 2009. Jatayu Restaurant. Pamphlet. Bird Conservation Nepal, Kathmandu.

Bird Conservation Nepal undated. Vulture ConservationProgramme. http://www.birdlifenepal.org/projects/vulture. htm Accessed 6 May 2009.

BirdLife International, Butterfly Conservation, Institute of Terrestrial Ecology, Oxford University, Plantlife and the Royal Society for Protection of Birds 1997.The indirect effect of pesticides on farmland birds. Department of Environment, Joint Nature Conservation Committee and English Nature, Peterborough. http://www.pmac.net/ukbirds.htm Accessed 9 January 2009.

BirdLife International 2008a. State of the world's birds. http://www.birdlife.org/sowb Accessed 16 December 2008.

BirdLife International 2008b. Europe's farmland birds continue to suffer from agricultural policy. http://www.birdlife.org/news/news/2008/12/m onitoring.html Accessed 16 December 2008.

BirdLife International 2008c. White-rumped Vulture Gyps bengalensis species fact sheet. http://www.birdlife.org/datazone/species/inde x.html?action=SpcHTMDetails .asp \& sid $=337$ $4 \& m=0$ Accessed 22 March 2009.

BirdLife International 2010. Lists of globally threatened and near-threatened species in Nepal. 


\section{Inskipp and H.S. Baral / Our Nature (2010) 8: 270-312}

http://www.birdlife.org/datazone/species/inde x.html Accessed 2 June 2010.

BirdLife International undated. Key grassland regions for threatened birds in Asia: Indo-Gangetic grasslands strategy.

http://www.birdlife.org/action/science/species /asia_strategy/pdf_downloads/grasslandsGO2. pdf Accessed 24 January 2010.

Bishop, B.C. 1990. Karnali under stress- livelihood strategies and seasonal rhythm in a changing Nepal Himalaya. The University of Chicago, Geography Research Paper Nos. 228-29. http://www.cababstractsplus.org/abstracts/Abs tract.aspx?AcNo=19916711853 Accessed 18 January 2010.

Bohle, H.-G. and J. Adhikari 1998. Rural livelihoods at risk. How Nepalese farmers cope with food insecurity. Mountain Research and Development 18(4): 321-332. http://www.jstor.org/pss/3674097 Accessed 18 January 2010.

Brown, S. and G. Kennedy 2005. A case study of cash cropping in Nepal: poverty alleviation or inequity? Agriculture and Human Values 22(1): 105-116.

Brown, S. and B. Shrestha 2000. Market-drive landuse dynamics in the middle mountains of Nepal. J. Environ. Manage. 59: 217-225. http://www.ingentaconnect.com/content/ap/ev /2000/00000059/00000003/art00355 Accessed 2 January 2009.

Cameron, J. 1995. Food security: background technical paper for the Agricultural Perspective Plan, Government of Nepal, Kathmandu.

Campilan, D., T.L. Lama, S.R. Ghimire and O. Hidalgo 2006. From piloting to scaling up. Leisa India. Pp.14-15, September 2006. http://www.leisa.info/index.php?url=getblob.p hp\&o_id=112051\&a_id=211\&a_seq $=0$ Accessed 17 February 2010.

Canadian Peregrine Foundation 2009. Peregrine biology: conservation issues. http://www.peregrinefoundation.ca/info/conservation.html Accessed 9 January 2009.
Central Bureau of Statistics 1994. National sample census of agriculture Nepal, 1991/92: Analysis of results, National Planning Commission Secretariat, Central Bureau of Statistics, Government of Nepal.

Central Bureau of Statistics 2001. Statistical Year Book of Nepal. Central Bureau of Statistics, National Planning Commission Secretariat, Government of Nepal.

Central Bureau of Statistics 2007. Statistical Year Book of Nepal. Eleventh edition. Central Bureau of Statistics, National Planning Commission Secretariat, Government of Nepal. http://www.cbs.gov.np/statistical_year_book_ content.php Accessed 8 February 2010.

Central Science Laboratory, Game ConserVancy Trust, Royal Society for the Protection of Birds and Department of Zoology, University of Oxford 2005. Assessing the indirect effects of pesticides on birds. PN0925. Final report. http://randd.defra.gov.uk/Document.aspx?Doc ument=PN0925_2486_FRP.pdf Accessed 1 June 2010.

Chaudhary, M.K. 2005. Farmers' Conservation Awareness Camp. BirdingASIA 3: 66-68.

Choudhary, B. 1996. More news from the largest heronry in Nepal. Bird Conservation Nepal Bulletin 5(4): 3 .

Cuthbert, R., R.E. Green, S. Ranade, S. SaraVanan, D.J. Pain, V. Prakash and A.A. Cunningham 2006. Rapid population declines of Egyptian vulture (Neophron percnopterus) and Redheaded vulture (Sarcogyps calvus) in India. Animal Conservation 9: 349-354. http://www3.interscience.wiley.com/journal/1 18731687/abstract Accessed 14 February 2010.

Dahal, L. 1995. A study in pesticide pollution in Nepal. National conservation strategy implementation project. IUCN/Nepal, Kathmandu.

DNPWC/MoFSC/GoN 2009. Vulture Conservation Action Plan for Nepal (2009-2013). Kathmandu. Government of Nepal, Ministry of Forests and Soil Conservation, Department 


\section{Inskipp and H.S. Baral / Our Nature (2010) 8: 270-312}

of National Parks and Wildlife Conservation. http://www.birdlifenepal.org/downloads/Vult ure\%20conservation\%20action\%20plan.pdf Accessed 14 February 2010.

DOAD. 1992. National Fisheries Development Plan, 1992/93. Fisheries Development Division, Department of Agriculture Development, HMGN, Kathmandu.

Forestry Nepal 2005. FAO releases final report of Forest Resources Assessment 2005. http://www.forestrynepal.org/artic le/news/274 Accessed 30 May 2010.

Gautam, M.K. 2000. Social impact assessment of South Asia Poverty Alleviation Programme: NepalSyanja a pilot study. Impact Assessment Technical Report.

SAPAP/UNDP/UNOPS/RAS United Nations Office for Project Services, Kuala Lumpur, Malaysia.

Ghimire, A. and B.P. Khatiwada 2001. Use of pesticides in commercial vegetable cultivation in Tandi, eastern Chitwan, Nepal during 2001. A survey report. http://www.forestrynepal.org/images/Use $\% 20$ of $\% 20$ Pesticides $\% 20$ in $\% 20$ Commercial $\% 20 \mathrm{~V}$ egetable\%20Cultivation.pdf Accessed 2 January 2009.

Ghimire, S.R. 2008. Environmental concern in Nepalese agriculture. Journal of Agriculture and Environment 9: 52-56.

http://journals.sfu.ca/nepal/index.php/AEJ/arti cle/view/21z15/1949 Accessed 11 September 2009.

Giri, J.B. and S. GC, 2005. Survey of nesting vultures in Royal Suklaphanta Wildlife Reserve, west Nepal. BirdingASIA 3: 9.

Giri, J.B., S. GC and J.B. Khadka 2004. Population and breeding success of White-rumped Vulture and Slender-billed Vulture in Royal Bardia National Park and Khairapur, Nepal. BirdingASIA 1: 9.

Gupta, P.K. 2004. Pesticide exposure-Ind ia scene. Toxicology 198: 83-90. In Atreya (2008).

Hanlon, D. and D. Giri 2007. Exploring the farmlands of Lumbini IBA. Danphe 16(1): 71-72. http://www.birdlifenepal.org/downloads/danp he_special_march_07.pdf Accessed 17 February 2010.

Himalayan Nature 2006. Farmland Bird Monitoring Programme. Unpublished.

HMGN/MFSC. 2002. Nepal biodiversity strategy. His Majesty's Government of Nepa1/Ministry of Forests and Soil Conservation, Kathmandu, Nepal. http://www.nepjol.info/index.php/AEJ/article/ viewArticle/2114 Accessed 17 February 2010.

Inskipp, C. 1989 Nepal's forest birds: their status and conservation. ICBP Monograph No. 4. International Council for Bird Preservation, Cambridge, UK.

Inskipp, C. and T. Inskipp 1991. A guide to the birds of Nepal. $2^{\text {nd }}$ edition. Christopher Helm, London, UK.

Inskipp, C. and T.P. Inskipp 1983. Results of a preliminary survey of Bengal Florican Houbaropsis bengalensis in Nepal and India 1982. International Council for Bird Preservation Study Report No. 2., Cambridge, UK.

Inskipp, C. and T. Inskipp 1994. Birds of Sagarmatha National Park. Unpublished report to Department of National Parks and Wild life Conservation, Kathmandu.

Institute of Science in Society 2005. Less is more for Nepali rice. 6 October2005. http://www.isis.org.uk/LIMFNR.php Accessed 17 February 2010.

IUCN Nepal 2004. A review of the status and threats to wetlands in Nepal. IUCN, The World Conservation Union, Kathmandu.

Joshi, G. and S. Pandey 2005. Effect of farmers' perceptions on the adoption of modern rice varieties in Nepal. Deutscher Tropentag 2005. Stuttgart-Hohenheim, October 11-13, 2005. Conference on International Agricultural Research for Development. http://www.tropentag.de/2005/abstracts/full/3 10.pdf Accessed 17 February 2010.

Kafle, G. and I.T. Savillo 2009. Present status of RAMSAR sites in Nepal. International Journal of Biodiversity and Conservation 


\section{Inskipp and H.S. Baral / Our Nature (2010) 8: 270-312}

1(5): 146-150.

http://www.academic journals.org/IJBC/PDF/ PDF2009/September/Kafle\%20and\%20Savill o.pdf Accessed 31 January 2010.

Kafle, G., M.K. Balla and B.K. Paudyal 2007. A review of threats to RAMSAR sites and associated biodiversity of Nepal. Tigerpaper 34(4): $1-5$.

http://www.fao.org/world/regional/rap/tigerpa per/Paper/TP34_4_001.pdf Accessed 31 January 2010.

Kafle, G., M.K. Balla and B.K. Paudyal 2008. A review of threats to RAMSAR sites and associated biodiversity of Nepal (Part II). Tigerpaper 35(1): 9-11. http://www.fao.org/world/regional/rap/tigerpa per/Paper/TP35_1_001.pdf Accessed 31 January 2010.

Karki, K. 2008. Effect of climate change in agriculture and livestock production. http://www.scribd.com/doc/3323985/Effectof-Climate-change-in-agriculture-andlivestock-production Accessed 2 June 2010.

Khanel, K.R. and K. Shrestha 2001. Tropical secondary forests in Nepal and their importance to local people. Journal of Tropical Forest Science 13(4): 691-704. http://www.cifor.cgiar.org/Publications/Docu mentDownloader? $\mathrm{a}=\mathrm{d} \& \mathrm{p}=\% 5$ Cpublications $\%$ 5Cpdf_files\%5Carticles\%5CAKane10101.pdf. Accessed 16 January 2010.

Khatiwada, J.R. and H. Chaudhary 2008a. Status of Wood Snipe Gallinago nemoricola and its conservation in Langtang National Park, central Nepal. Final report to Oriental Bird Club, UK. Unpublished. Accessed $17 \mathrm{f}$

Khatiwada, J.R. and H. Chaudhary 2008b. Status of Wood Snipe Gallinago nemoricola and its conservation in Langtang National Park, central Nepal. BirdingASIA 10: 7-8.

Koirala, P. Dhakal, S. and Tamrakar, A. S. 2009. Pesticide application and food safety in Nepal. Journal of Agriculture and Environment 10: 111-114. http://journals.sfu.ca/nepal/index.php/AEJ/arti cle/view/2137/1967 Accessed 11 September 2009.
Koirala, P., D.B. Khadka and A. Mishra 2007. Pesticide residues as environmental contaminants in foods in Nepal. Journal of Agriculture and Environment 8:96-100. http://www.nepjol.info/index.php/AEJ/article/ viewArtic le/753 Accessed 8 May 2009.

Lyons, G. 1999. Endocrine disrupting pesticides Pesticides News 46: 16-19. http://www.panuk.org/pestnews/Actives/endocrin.htm Accessed 9 January 2009.

MacDonald, M.A. 2006. The indirect effects of increased nutrient inputs on birds in the UK: a review. RSPB Research Report 21. Royal Society for the Protection of Birds, Sandy, UK.

Malla, G. 2008. Climate change and its impact on Nepalese agriculture. The Journal of Agriculture and Environment 9: 62-71. http://www.nepjol.info/index.php/AEJ/article/ viewFile/2119/1952 Accessed 2 June 2010.

Maltsoglou, I. and K. Taniguchi 2004. Poverty, livestock and household typologies in Nepal. Pro-Poor Livestock Policy Initiative Working Papers 23784, Food and Agriculture Organization of the United Nations, http://ideas.repec.org/p/fao/wpaper/0415.html Accessed 24 January 2010.

Mills, D.G.H. and N.A. Preston 1981. Notes on birds recorded in Nepal, 1981. Unpublished.

Ministry of Agriculture and Cooperatives, Government of Nepal (a) Agricultural statistics summary 2004/05. http://www.aicc.gov.np/database.php Accessed 11 September 2009.

Ministry of Agriculture and Cooperatives, Government of Nepal (b) Area, production and yield of cereal crops in Nepal, 1950/512003/04.

http://www.moacwto.gov.np/statistics/Cereal Crops.pdf Accessed 11 September 2009.

Ministry of Agriculture and Cooperatives, Government of Nepal (c) Area, production and yield of oilseed, potatoes and sugar cane, 1964/65-2003/04.

http://www.moacwto.gov.np/statistics/Cash_ Crops.pdf Accessed 11 September 2009. 


\section{Inskipp and H.S. Baral / Our Nature (2010) 8: 270-312}

Ministry of Agriculture and Cooperatives, Government of Nepal (d) Area, production and yield of vegetables, 1964/65 - 2004/05. http://www.aicc.gov.np/database/agriculture_s tstistics/ national_level_data/Area, $\% 20$ production $\% 20$ and $\% 20$ yield $\% 20$ of $\% 20$ vegertables.pdf Accessed 11 September 2009.

Ministry of Agriculture Fertilizer Unit. 2002 National FertilizerPolicy. http://www.fadinap.org/nepal/policy.html Accessed 8 January 2009.

Ministry of Environment, Science and Technology (MoEST) 2006. Rural Energy Policy. Kathmandu.

Ministry of Environment, Science and Technology (MoEST) 2005. Inventory of pesticides in Nepal. POPs enabling activities project. MoEST, Kathmandu.

National Toxics Network 2007. Overview of the impact of air and water pollution on flora and fauna. China Skillshare on Chemical Safety, Beijing, October $16^{\text {th }}-20^{\text {th }}, 2007$. http://ntn.org.au/ntndocs/ntnpollutionrefpaper. pdf Accessed 9 January 2009.

Nepal Development Information Institute 2006. Nepal District Profile 2006. Kathmandu, Nepal.

Nepal Forum for Justice 2006. Governmental and public awareness-raising on POPs. International POPs Elimination Project. http://www.ipen.org/ipepweb1/library/ipep_p df_reports/4nep $\% 20$ gov\%20and $\% 20$ public $\% 2$ 0awareness\%20raising\%20on\%20pops.pdf Accessed 6 January 2009.

NPC. 2007. Three Year Interim Plan. National Planning Commission, Government of Nepal, Kathmandu, Nepal.

Oaks, J.L., M. Gilbert, M.Z. Virani, R.T. Watson, C.U. Meteyer, B. Rideout, H.L. Shivaprasad, S. Ahmed, M.J.I. Chaudhry, M. Arshad, S. Mahmood, A. Ali and A.A. Khan 2004. Diclofenac residues as the cause of vulture population decline in Pakistan. Nature 427: 630-633.

Ojha, H., L. Persha and A. Chhatre 2009. Community forestry in Nepal: A policy innovation for local livelihoods and food security.
International Food Policy Research Institute. Working Paper No. W09I-02. Ann Arbor, Michigan, USA. http://www.forestrynepal.org/publications/foo d-security/4352 Accessed 18 January 2010.

Palikhe, B. 1999. Pesticide management in Nepal: implementation issues and experiences. Paper presented at the workshop 'Present Environmental Challenges and Management of Pesticides, Chemical Fertilisers and Solid Waste', 3-4 October. SEJ, Kathmandu.

Palikhe, B. 2007. Relationship between pesticide use and climate change for crops. J. Agri. Environ. 8: 83-91. http://www.nepjol.info/index.php/AEJ/article/ viewArticle/731 Accessed 5 January 2009.

Palikhe, B.R. 2005. Pesticide management in Nepal. In view of Code of Conduct. Paper presented at the Regional Workshop on International Code of Conduct on the Distribution and Use of Pesticides: Implementation, Monitoring and ObserVance, Bangkok, Thailand, 26-28 July 2005.

Pandey, P.R., H. Pandey and M. Nakagawa 2009. Assessment of rice and maize based cropping systems for rural livelihood improvements in Nepal. J. Agri. Environ. 10: 57-64. http://www.nepjol.info/index.php/AEJ/artic le/ view/2131/0 Accessed 17 February 2010.

Pant, K.P. 2007. Environmental implications of agricultural trade in Nepal. J. Agri. Environ. 8: 30-37. http://www.nepjol.info/index.php/AEJ/artic le/ viewArticle/724 Accessed 24 January 2010.

Parajuli, A.V. 2005. Global forest resources assessment 2005 Nepal country report. Country Report no.192, Food and Agricultural Organization, Rome, Italy. http://www.fao.org/forestry/8859-0-35.pdf Accessed 29 May 2010.

Paudel, L.N., C. Wollny and M. Gauly 2009. Socioeconomic and biophysical conditions for the sustainable livestock management: a case study for Nepal. Biophysical and Socioeconomic Frame Conditions for the Sustainable Management of Natural Resources Conference. Tropentag, October 68, 2009, Hamburg, Germany. 


\section{Inskipp and H.S. Baral / Our Nature (2010) 8: 270-312}

http://www.tropentag.de/2009/abstracts/links/ Paudel_r0QxiWed.pdf Accessed 17 January 2010.

Paudel, S. 2009a. Study on threats to Sarus Crane Grus antigone antigone in farmlands in Lumbini, an Important Bird Area of NepalAEC/OBC Award 2007. BirdingASIA 12: 910.

Paudel, S. 2009b. Study on threats to Sarus Crane Grus antigone antigone in farmlands in Lumbini, An Important Bird Area of Nepal. A final report submitted to Oriental Bird Club, UK. Unpublished.

Peet, N. 1997. Biodiversity and management of tall grasslands in Nepal. University of East Anglia, UK. (Ph.D. thesis)

Pesticides Registration and Management Section 2006. Pesticides registration and management program: Introduction, achievements and directives. Ministry of Agriculture and Cooperatives, Department of Agriculture, Kathmandu. (In Nepali). In Atreya (2008).

Plant Protection Directorate. 2003. Crop protection program: introduction, achievements and operational procedures. Ministry of Agriculture and Cooperatives, Department of Agriculture, Kathmandu. (In Nepali). In Atreya (2008).

Plant Protection Directorate. 2007. Annual progress report. Pesticide Registration and Management Section, Pla 4RBP72BUnt Protection Directorate. In Pokhrel, D. M. and Pant K. P. (2009) Perspectives of organic agriculture and policy concerns in Nepal. $J$. Agri. Environ. 10: 89-99. Accessed 11 September 2009.

Porter, R.F., W.E. Oddie and B.A.E. Marr 1981. Notes on birds recorded in Nepal, February 1981. Unpublished.

Ramsar Convention Secretariat 2004. The Annotated Ramsar List, English Language Edition. Ramsar Convention Secretariat, Gland, Swirzerland.

Rand, A.L. and R.L. Fleming 1957. Birds of Nepal. Fieldiana: zool. 41: 1-218. http://ia351443.us.archive.org/3/items/birdsfr omnepal411rand/birdsfromnepal411rand.pdf

Regmi, R.R. 1994. Deforestation and rural society in the Nepalese terai. Occasional Papers in Sociology and Anthropology 4: 72-89. http://www.nepjol.info/index.php/OPSA/articl e/viewArtic le/1086 Accessed 16 January 2010.

Riley, P., S. Bell and M. Warhurst 1999. Endocrinedisrupting pesticides. Friends of the Earth Briefing. http://www.foe.co.uk/resource/briefings/endo crine_disrupting.html Accessed 9 January 2009.

Royal Society for the Protection of Birds 2009. Peregrine: population trends. http://www.rspb.org.uk/wildlife/birdguide/na me/p/peregrine/population.asp Accessed 9 January 2009.

Sah, J.P. 1997. Koshi Tappu wetlands. Nepal's Ramsar site. IUCN Bangkok, Thailand.

Sankaran, K.V. undated. Mikania micrantha Mile-aminute weed. Invasive Pest Fact Sheet. AsiaPacific Forest Invasive Species Network. http://www.doacs.state.fl.us/pi/enpp/botany/i mages/mikania-pest-fact-sheet-APFISN.pdf Accessed 14 February 2010.

Santa Cruz Predatory Bird Research Group 2007. Peregrine Falcons and DDT. http://www2.ucsc.edu/scpbrg/ddt.htm Accessed 9 January 2009

Sapkota, L. 2007. Ecology and management issues of Mikania micrantha in Chitwan National Park, Nepal. Banko Janakari 17(2): 27-39. http://www.nepjol.info/index.php/BANKO/ article/view/2153/1981 Accessed 14 February 2010.

Shah, B.P. and B. Devkota 2009. Obsolete pesticides: their environmental and human health hazards. J. Agri. Environ. 10: 51-56. http://journals.sfu.ca/nepal/index.php/ AEJ/article/view/2130/1961 Accessed 11 September 2009.

Shah, R.C. 2006. Pesticides and POPs in Nepal: status, problems and solutions (in Nepali). In Pesticides and POPs management (Ed. R.C. 


\section{Inskipp and H.S. Baral / Our Nature (2010) 8: 270-312}

Shah). Center for Public Health and Environmental Development, Kathmandu, Nepal. 130 p. In Atreya (2007b).

Sharma, K.C. 1994. Current experiences and practices in pesticide use in the Bagmati zone, ADPI Series. No. 9, ICIMOD, Kathmandu. In Ghimire and Khatid wada (2001).

Sharma, P.S. 1996. Forest fire behaviour study in saldominated natural forests in terai. Working Paper 23. Forest Management and Utilisation Development Project (FMUDP) HMGN/FINNIDA.

Sharma, U.R. and W.W. Shaw 1997. Park-people interactions in Royal Chitwan National Park, Nepal. Environ. Cons. 20(2): 139-142.

Shrestha, P.L. and F.P. Neupane 2002. Socioeconomic contexts on pesticide use in Nepal. In International workshop on environmental risk assessment of pesticides and integrated pest management in developing countries (Eds. A. Hermann and S. Schumann). Kathmandu, Nepal. Landschaftsokologie und Umweltforschung 38: 202-223.

Braunschweig, Germany. http://www.tubraunschweig.de/Medien$\mathrm{DB} /$ geooekologie/nepal-shrestha-neupane.pdf Accessed 5 January 2009.

Shrestha, V.P. 1994. Environmental problems in the Nepal Himalaya. Contributions to Nepalese Studies 21(2): 137-151.

Shrestha, V.P. 1999. Forest resources of Nepal: destruction and environmental implications. Contributions to Nepalese Studies 26(2): 295307.

http://himalaya.socanth.cam.ac.uk/collections/ journals/contributions/pdf/CNAS_26_02_08.p df 16 January 2010.

Shultz, S., H.S. Baral, S. Charman, A. Cunningham, D. Das, G.R. Ghalsasi, M.S. Goudar, R.E. Green, A. Jones, P. Nighot, D.J. Pain and V. Prakash 2004. Diclofenac poisoning is widespread in declining vulture populations across the Indian subcontinent. Proceedings of Royal Society of London DOI 10.1098.

Singh, S. 2007. Conservation of farmland bird communities of Lumbini, central lowland Nepal. Final report submitted to the Forestry
Bureau, Council of Agriculture, Taiwan. Unpublished.

Siwakoti, M. 2007. Mikania weed: a challenge for conservationists. Our Nature 5: 70-74. http://www.nepjol.info/index.php/ON/artic le/ viewFile/801/770 Accessed 14 February 2010.

Smith, P., D. Martino, Z. Cai, D. Gwary, H.H. Janzen, P. Kumar, B. McCarl, S. Ogle, F. O'Mara, C. Rice, R.J. Scholes, O. Sirotenko, M. Howden, T. McAllister, G. Pan, V. Romanenkov, U. Schneider, S. Towprayoon, M. Wattenbach and J.U. Smith 2008. Greenhouse gas mitigation in agriculture. Philosophical Transactions of the Royal Society. B. 363: 789-813.

Subedi, T.R. 2008. Status and conservation of Red Panda Ailurus fulgens in Dhorpatan Hunting Reserve, Nepal. Rufford Small Grants for NatureConservationProject. http://www.ruffordsmallgrants.org/rsg/project s/tulsi_ram_subedi Accessed 16 January 2010.

System of Rice Intensification Group 2009. The System of Rice Intensification. Nepal. http://ciifad.cornell.edu/SRI/countries/nepal/i ndex.html Accessed 17 February 2010.

Takahatake, T. 2001. The benefits and problems of cash crop farming in eastern Nepal: a case study of Ilam district. Journal of International Development and Cooperation 8(1): 127-146. http://ir.lib.hiroshimau.ac.jp/metadb/up/74007022/JIDC_08_01_08 _Takahatake.pdf Accessed 17 December 2008.

TAL Program 2009. Annual Progress Report June 2008-2009. Protected Area and Buffer Zone, TAL Program. A report to the DNPWC. Unpublished.

Television Trust for the Environment 2004. Paddy chronicles, Judi 572-Nepal. http://www.tve.org/ho/series5/04_Paddy\%20 Chronic les.html Accessed 17 February 2010.

Thapa, I. and B.R. Dahal 2009. Sustainable wetland management for wild life and people at Koshi Tappu Wildlife Reserve. Banko Janakari Wetlands Special Issue. 


\section{Inskipp and H.S. Baral / Our Nature (2010) 8: 270-312}

http://www.nepjol.info/index.php/BANKO/iss ue/view/171

Thapa, Y.V. 2006. Constraints and approach for improving fertilizer supply for meeting domestic demand. Economic Policy Network Policy Paper 30. Report to Economic Policy Network and Asian Development Bank, Kathmandu.

http://www.mof.gov.np/economic_policy/pdf/ Constraints_Approach.pdf Accessed 8 January 2009.

Tiwari, K.R., B.K. Sitaula, R.M. Bajracharya and T. BØrresen 2009. Runoff and soil loss responses to rainfall, land use, terracing and management practices in the Middle Mountains of Nepal. Acta Agriculturae Scandinavica, Section B-Plant Soil Science 59(3): 197-207.

http://www.informaworld.com/smpp/content content $=\mathrm{a} 793948871 \sim \mathrm{db}=$ all Accessed 20 January 2010.

Tiwari, S., B. Adhikari, M. Siwakoti and K. Subedi 2005. An inventory and assessment of invasive, alien plant species of Nepal. IUCN Nepal, Kathmandu

Tucker, G.M. and M.F. Heath 1994. Birds in Europe: their conservation status. BirdLife Conservation Series No. 2. BirdLife International, Cambridge, UK.

Tumbahangphey, A. 2006. Is there poison in your neighbourhood? Nepali Times Issue 283. 27 January- 02 February, 2006. http://www.nepalitimes.com.np/issue/283/Nat ion/10204 Accessed 6 January 2009.

Tyler, S. J. and S. J. Ormerod 1993. The ecology of river birds in Nepal. Forktail 9: 59-82.
Uprety, R. 2004. System of Rice Intensification in the context of Nepalese rice production. http://ciifad.cornell.edu/SRI/countries/nepal/n epalrptuprety04.pdf. Accessed 17 February 2010.

Van der Weijen, W. 2010. Introduction. In Farmland birds across the world. (Eds. W. Van der Weijden, P. Terwan and A. Guldemond). Lynx Edicions, Barcelona, Spain. 138 p.

Van der Weijen, W., P. Terwan and A. Guldemond 2010. The future of farmland birds. pp.115121. In Farmland birds across the world. (Eds. W. Van der Weijden, P. Terwan and A. Guldemond). Lynx Edicions, Barcelona, Spain. 138 p.

Wallace, M.B. 1988. Forest degradation in Nepal: Institutional context and policy alternatives. Research Report Series \#6. HMGUSAIDGTZIDRC-Ford-Winrock project: strengthening institutional capacity in the food and agricultural sector in Nepal.

World Bank 2010. Key development data and statistics Nepal. http://datafinder.worldbank.org/populationtotal Accessed 14 February 2010.

World Food Programme 2010. Nepal. http://www.wfp.org/countries/nepal Accessed 12 February 2010.

WWF Nepal 2007. Annual Report 2006-07. WWF Nepal, Kathmandu.

WWF Nepal 2008. Annual Report 2007-08. WWF Nepal, Kathmandu.

www.fao.org/world/regional/rap/meetings/2005/Jul26 /Documents/Nepal\%20Paper.doc Accessed 6 January 2009. 